Aroueología Y SociedAd

№ 26, 2013: 131-164

ISSN: 0254-8062

\title{
EL COMPLEJO AROUEOLÓGICO CAMPANARIO Y LA PRESENCIA DE CERÁMICA CASMA INCISA Y APLICADA EN ELVALLE DE HUARMEY, COSTA NOR-CENTRAL DEL PERÚ
}

\author{
LUIS ZaVALETA PAREDES \\ LICENCIADO EN AROUEOLOGÍA \\ enrique.zavaleta@gmail.com \\ Rocío del PILAR SÁNCHEZ MENDOZA \\ LICENCIADA EN ARQUEOLOGÍA \\ rociosanchez3o@hotmail.com
}

\section{RESUMEN}

A partir de evidencias arquitectónicas y cerámicas se ha identificado que alrededor del año 1000 d.c. el Complejo Campanario se constituyó en el centro político y religioso del valle de Huarmey. En el presente artículo se identifican las áreas funcionales de este asentamiento y se detallan las características de la cerámica local, definiendo el Estilo Campanario; se propone una cronología relativa para el sitio a partir de contextos reportados en superficie y se evalúa el tipo de organización sociopolítica que pudo imperar en el valle de Huarmey entre los siglos XI a XIV d.C.

Palabras Clave: Complejo, centro político religioso, áreas funcionales, arquitectura, plataforma, área urbana, conjunto, cerámica Casma, Casma Inciso y Aplicado.

\section{Abstract}

Based on ceramic and architectural evidence collected from the archaeological complex of Campanario, we identify this site as the political and religious center in the valley of Huarmey around AD 1000. In this article we discuss the activity areas of Campanario and present detailed description of a local style of ceramic which we are calling the Campanario Style. Artifacts and features from surface contexts have allowed us to reconstruct the occupational history and site chronology of Campanario. The results of our analyses have furthered our understanding of the type of sociopolitical organization operating in the Huarmey Valley during the Late Intermediate Period (AD 900-1400).

KeYwords: Complex, politico-religious center, activity areas, architecture, platform, urban area, compound, Casma ceramic, Casma Incised and Applique. 


\section{INTRODUCCIÓN}

El complejo arqueológico Campanario está localizado a $1 \mathrm{~km}$ al noreste de la ciudad de Huarmey, sobre las últimas estribaciones andinas y el inicio del cono de deyección de la quebrada Pedregal y el cerro Campanario, este último da nombre a toda el área. Geográficamente el complejo se ubica a 780' $37,54^{\prime \prime}$ de longitud oeste y a 1003'34.31" de latitud sur y a una altitud de $30 \mathrm{msnm}$. Fue reportado por Bonavia como el sitio PV 35-80 (1982: 439). La ocupación prehispánica de Campanario está asociada a un estilo cerámico que ha sido reportado desde el valle de Huarmey hasta Chao (Fig. 1).

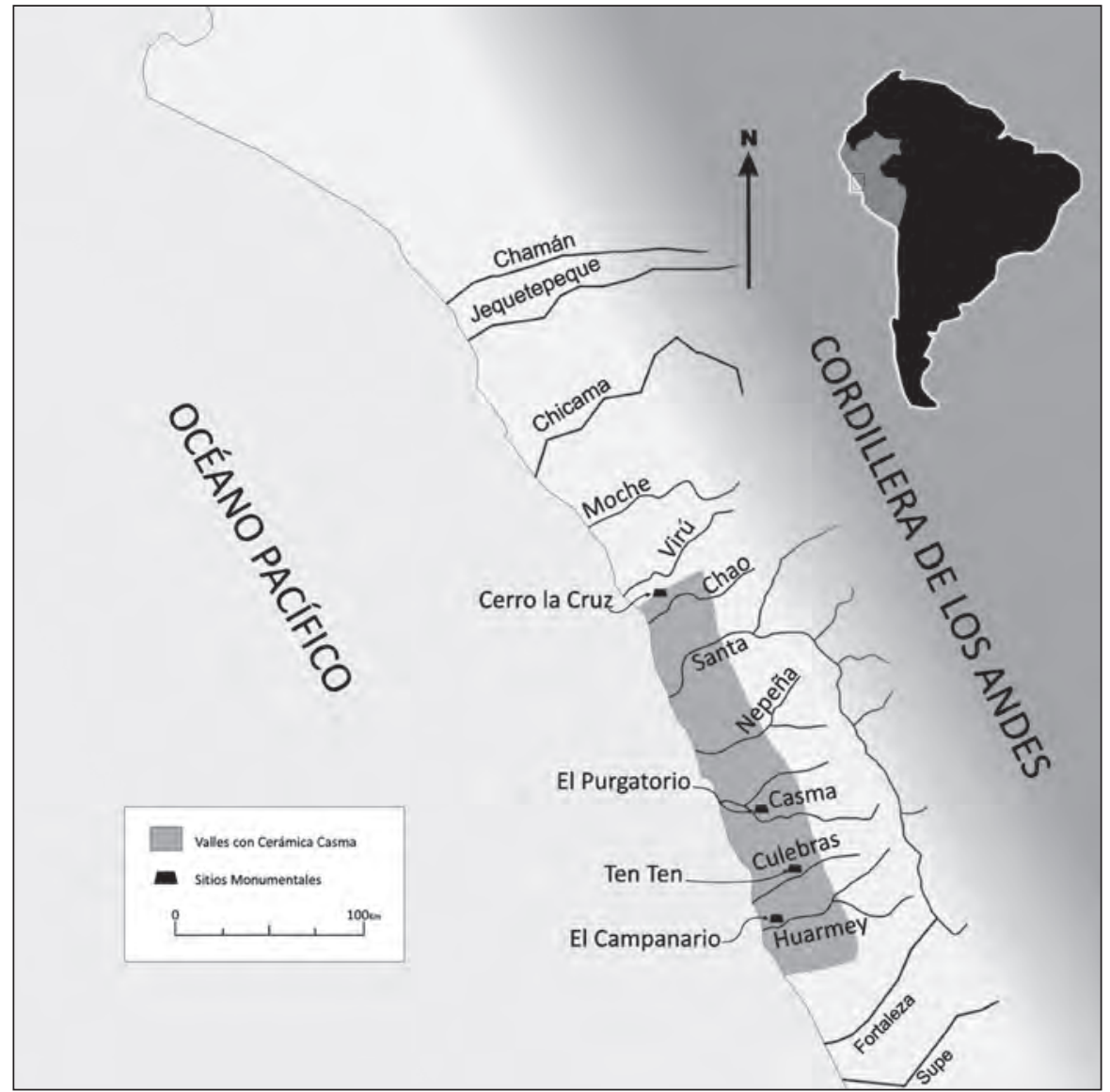

Figura 1. Ubicacion del valle de Huarmey y valles adyacentes con presencia de ceramica Casma Incisa y Aplicada.

En la actualidad el crecimiento urbano y agroindustrial en la ciudad de Huarmey amenaza seriamente la preservación del sitio. El lado suroeste del ingreso al complejo ha sido ocupado por viviendas y gran parte del sitio y su entorno es usado para arrojar los desechos de la ciudad o como canteras para la obtención de materiales de construcción; por otro lado, la erosión eólica y pluvial afecta las evidencias culturales del complejo. Ante esta situación optamos por efectuar esta investigación basada en una prospección superficial sin excavaciones y registrando in situ la evidencia cerámica y la arquitectura.

El registro de la arquitectura de este asentamiento ha permitido inferir la disposición espacial y el diseño de sus áreas funcionales. Asimismo, se presenta una descripción y clasificación de la cerámica. También se trata sobre los recursos naturales que hacían atrayente al valle de Huarmey. 


\section{El Complejo Campanario y sus ÁREAS DE ACTIVIDAd}

La arquitectura y su asociación con elementos culturales ha permitido dividir el sitio en cinco sectores: una plataforma cercada por tres muros concéntricos, arquitectura administrativa y residencial de elite, en cerro Campanario; el sector con arquitectura urbana, los depósitos y los cementerios (Figs. 2 y 3 ).

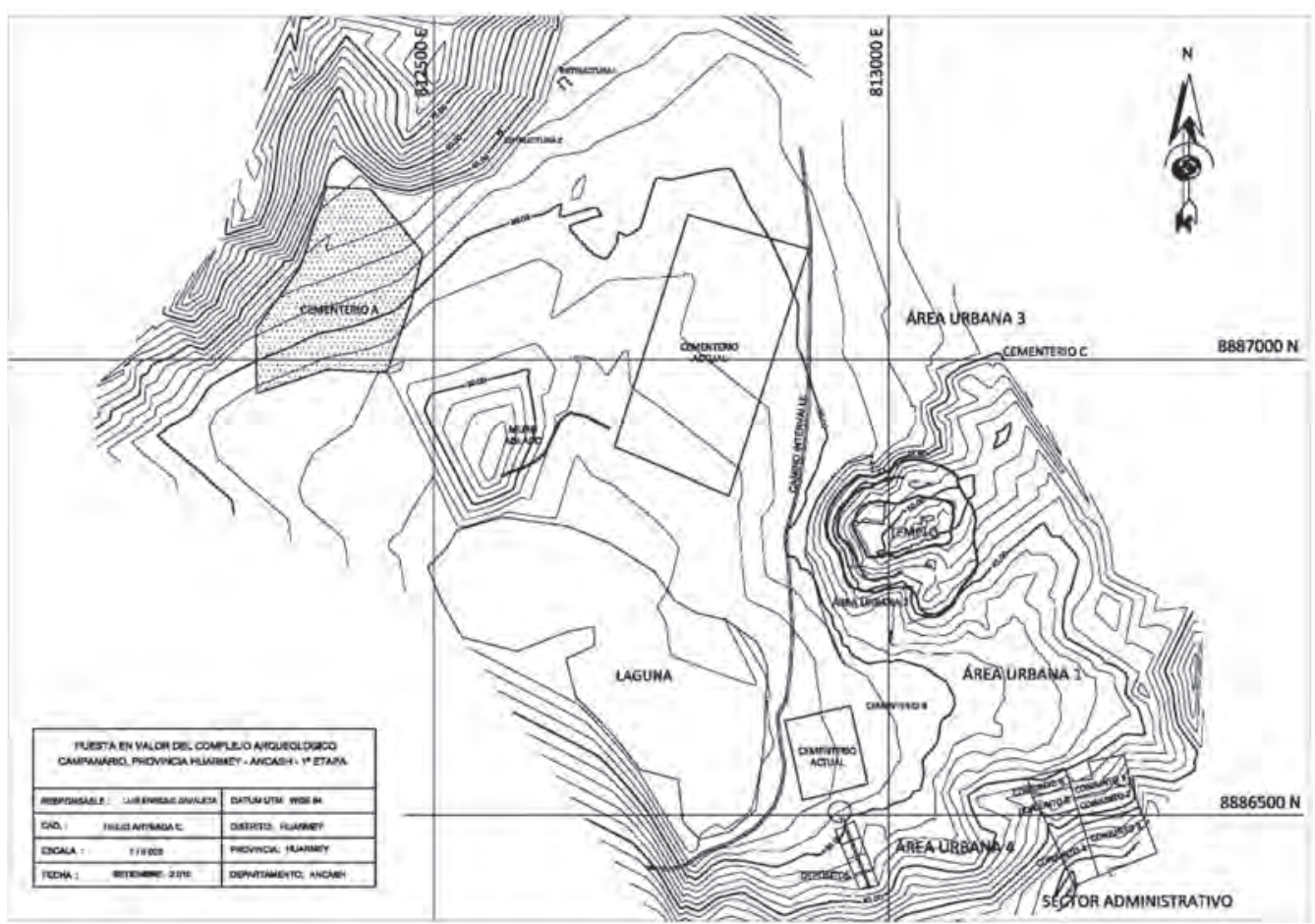

Figura 2. Distribucion espacial y areas de actividad.

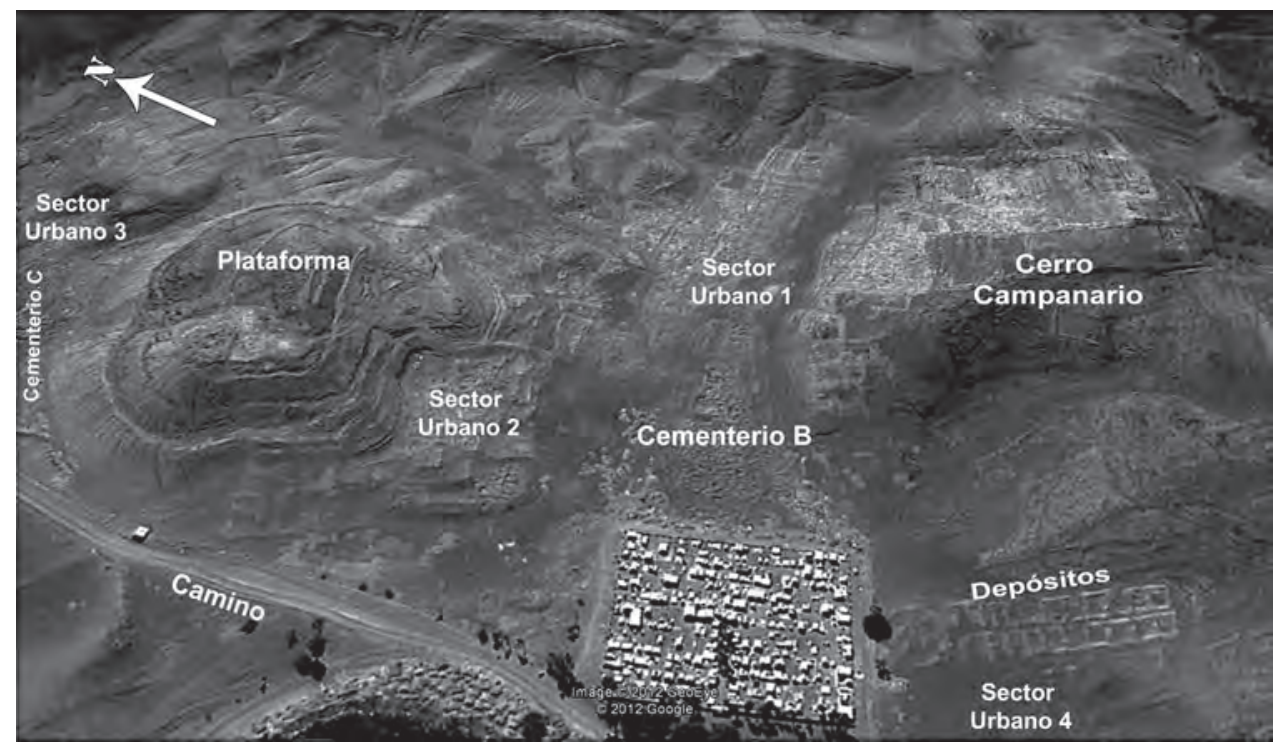

Figura 3. Foto satelital indicando areas funcionales (Google Earth 2013). 


\section{PLATAFORMA CERCADA POR TRES MUROS CONCÉNTRICOS}

Se trata de una plataforma de adobes construida sobre un afloramiento rocoso (Fig. 4), esta rodeado por tres muros, cada uno mide $1,40 \mathrm{~m}$ de ancho (Fig. 5). Por la irregularidad del afloramiento los muros han sido adaptados a la topografía del terreno. Los muros están construidos con adobes colocados en hiladas intercaladas una de costilla y otro combinando un adobe de soga y otro de cabeza, sus adobes miden en promedio $37 \mathrm{~cm}$ de largo, $14 \mathrm{~cm}$ de ancho y $9 \mathrm{~cm}$ de espesor. El muro central solo está presente en el lado oeste, pero es evidente que se planeó su construcción, porque se observa la nivelación en la ladera este y norte del cerro e incluso el amontonamiento de piedras retiradas para nivelar el área a construir, por alguna razón no se culminó este proyecto. En el frontis oeste, de esta plataforma, en la cabecera del primer muro que la rodea; se observan incrustados horizontalmente varas de algarrobo, quizás se trata de componentes de las técnicas constructivas o vigas que soportan una cubierta.

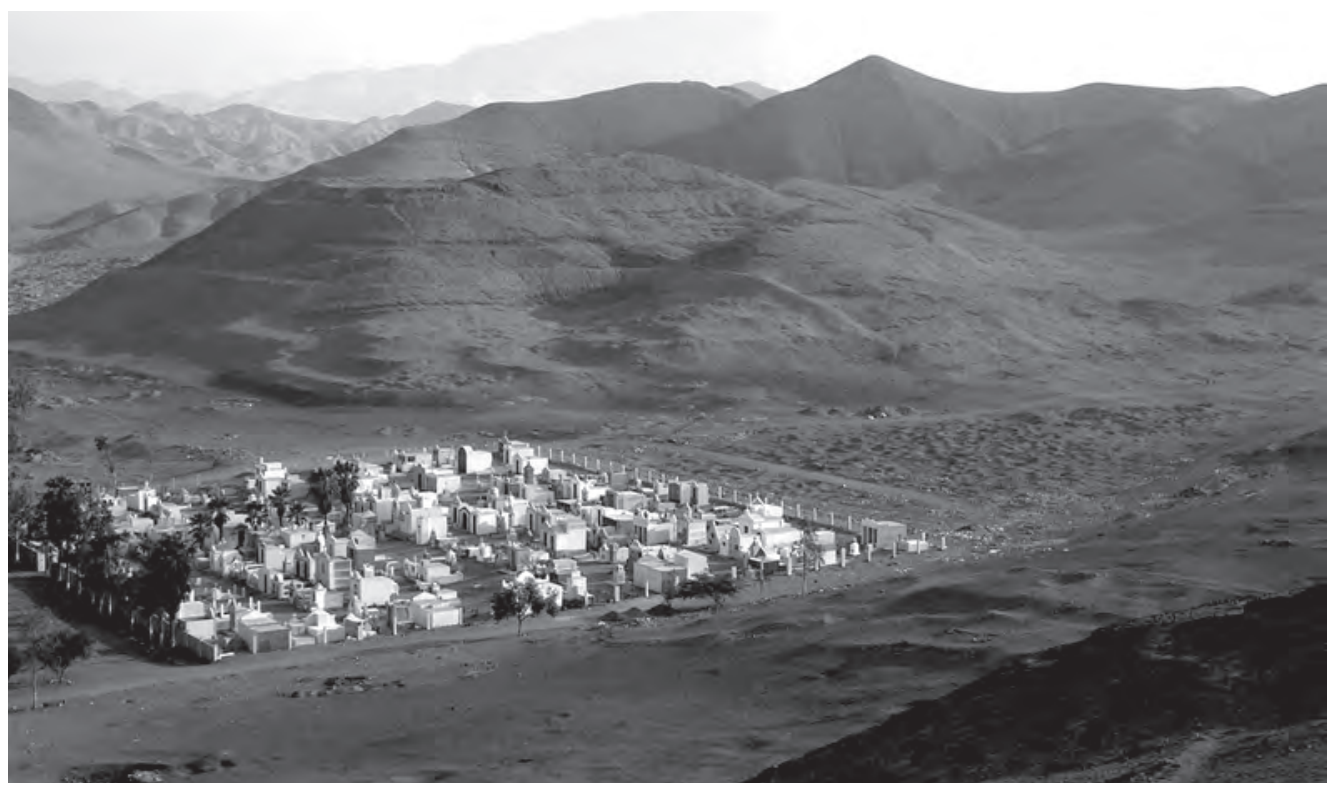

Figura 4. Vista general de la plataforma.

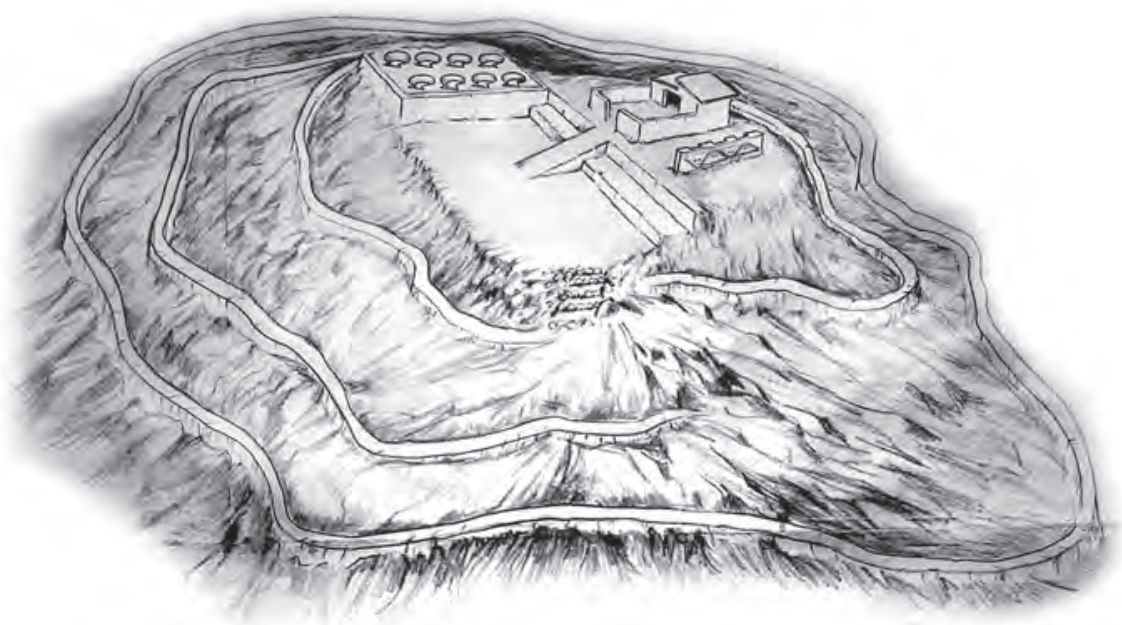

Figura 5. Reconstruccion hipotetica de la plataforma. Dibujo de Jorge Solórzano. 
La Plataforma, en la parte superior presenta dos niveles:

\section{Nivel alto}

Situado a $66 \mathrm{msnm}$, tiene un ambiente cuadrangular construido con adobes y piedras, está asociado a huesos humanos y camélidos, toda esta arquitectura está en mal estado de conservación y ha sido saqueada intensamente. Hacia el suroeste se encuentra un muro que en su paramento sur tiene relieves (Figs. 6 y 7); la presencia de adobes tramados que soportan los relieves indica que al construirse dicho muro ya se había planificado todas las características de los elementos que irían sobre este. Los relieves representan al pez raya o serpientes, son escalonados y se alternan uno mirando hacia arriba y otro hacia abajo, presentan dos ojos y una boca configuradas a partir de espacios en plano relieve exprofesamente dejados en el muro. Las medidas de cada relieve son $62 \mathrm{~cm}$ de ancho por $40 \mathrm{~cm}$ de

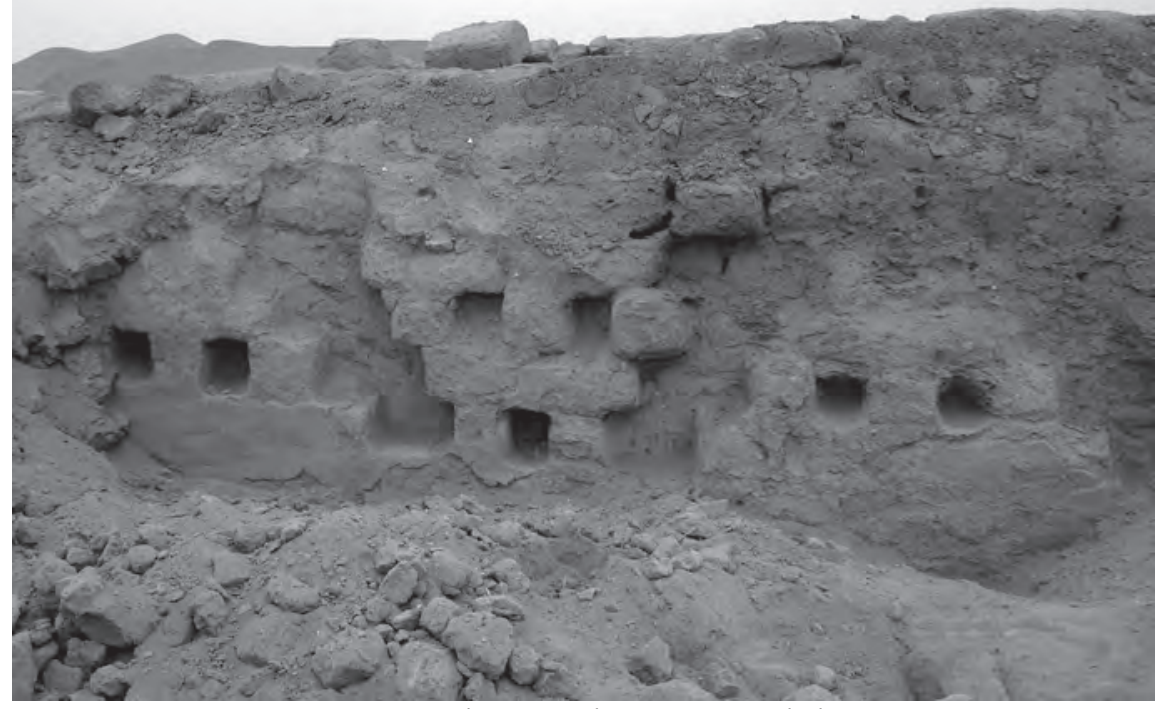

Figura 6. Relieves en el muro sur nivel alto.

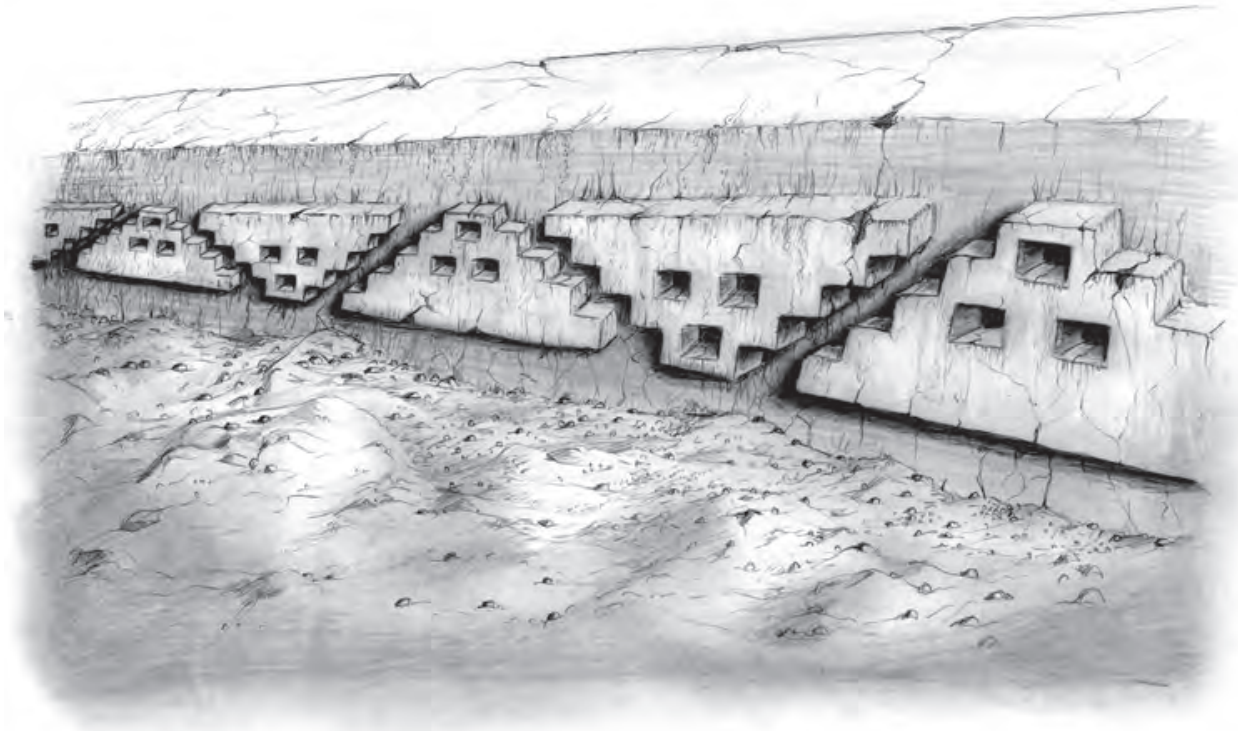

Figura 7. Recostruccion de relieves en muro sur. Dibujo de Jorge Solórzano. 
alto, los ojos, diseñados de forma cuadrada, miden $9 \mathrm{~cm}$ por lado y la boca rectangular $11 \mathrm{~cm}$ de largo por $6 \mathrm{~cm}$ de ancho. La técnica de elaboración fue a partir de un diseño planificado en el muro soporte que se conformaba de adobes paralelepípedos asentados de cabeza, estos sobresalen de forma alterna y simétrica, en promedio, $15 \mathrm{~cm}$ sobre el paramento sur, creando formas escalonadas y cuadradas que dan forma a los extremos, la nariz y la boca de cada relieve, esta técnica da estabilidad a los relieves creando una semejanza con un plano relieve. Las juntas de los adobes presentan barro y los acabados de los relieves se lograron con un pañeteado de arcilla con temperante de arena fina que rellenó las uniones y que fue modelado dando forma al relieve.

En el paramento norte del muro con los relieves, apenas se pueden observar las bases de cuatro hornacinas en muy mal estado de conservación que miden $1 \mathrm{~m}$ de ancho y están separados por otro pequeño espacio de $8 \mathrm{~cm}$ de ancho. En el lado norte se observa varias capas de material vegetal usado para estabilizar una terraza de material suelto y poder conformar las bases sólidas para una superficie de uso.

\section{Nivel bajo}

Tiene una altura de $58 \mathrm{msnm}$, se ubica al oeste y tiene dos espacios definidos: una plaza al sur (Fig. 8) con las medidas $40 \mathrm{~m}$ de largo por $18 \mathrm{~m}$ de ancho con su eje mayor de norte a sur. El otro espacio en el lado norte delimitado por un muro que mide $30 \mathrm{~m}$ de largo por $80 \mathrm{~m}$ de ancho, se localiza un área funeraria conformada por cámaras circulares (Fig. 9) construidas sobre la roca madre con muros de $0,70 \mathrm{~m}$ de ancho y un diámetro de 2,65 m. La única cámara visible y en buen estado de conservación presenta un acceso escalonado en el lado sur oeste (Fig. 10), su paramento se presenta enlucido con una arcilla de color amarillo dando la apariencia de decoración, el hallazgo de restos de caña bambú, soguillas, textiles, restos de cerámica, algarrobo y huesos humanos que incluyen algunos cráneos, con deformación, son evidencias de espacios que estuvieron originalmente techados y que habrían contenido cuerpo asociados a textiles; se trataría de la tradición pan andina de adoración a momias de acuerdo a un calendario ritual y en donde éstas recibían un tratamiento cíclico como lo señala

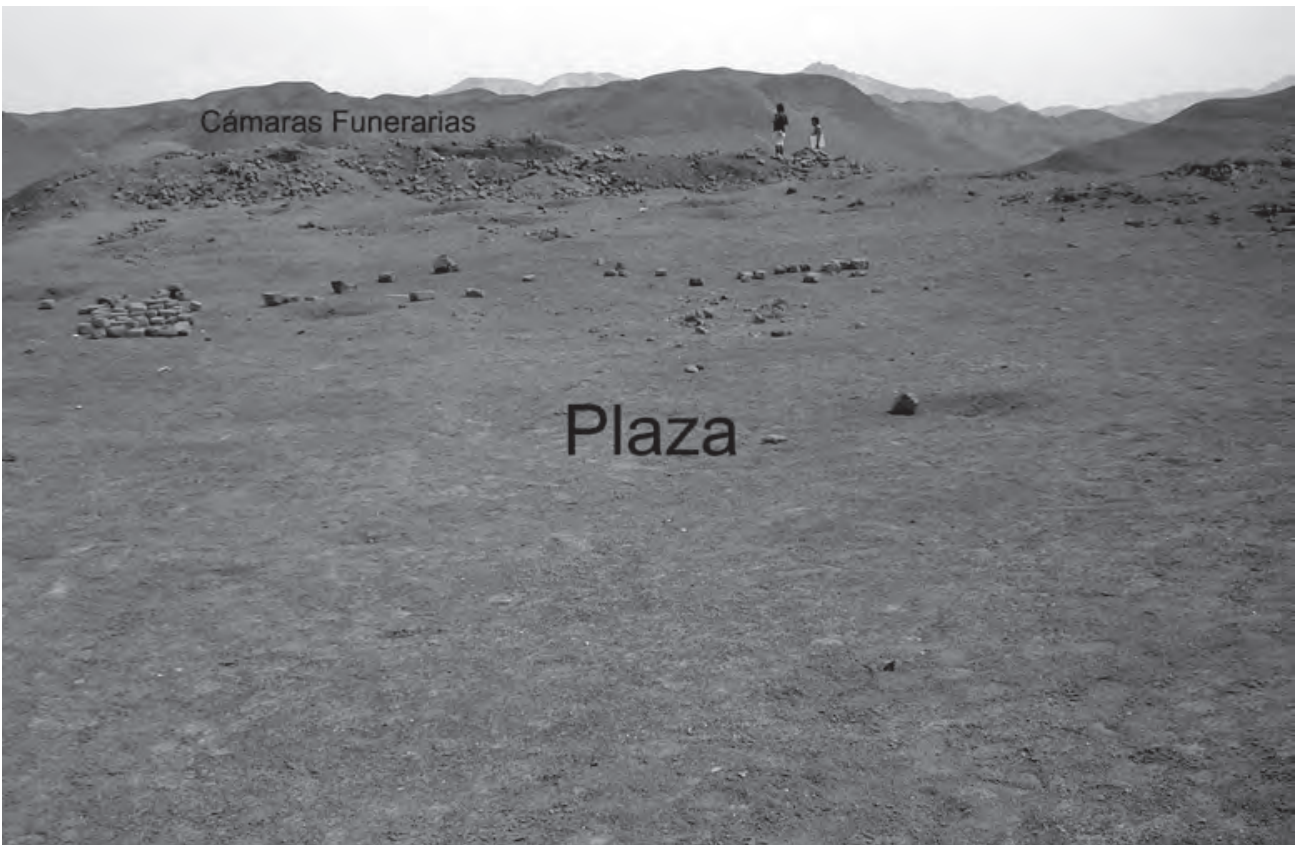

Figura 8. Nivel bajo, plaza. 


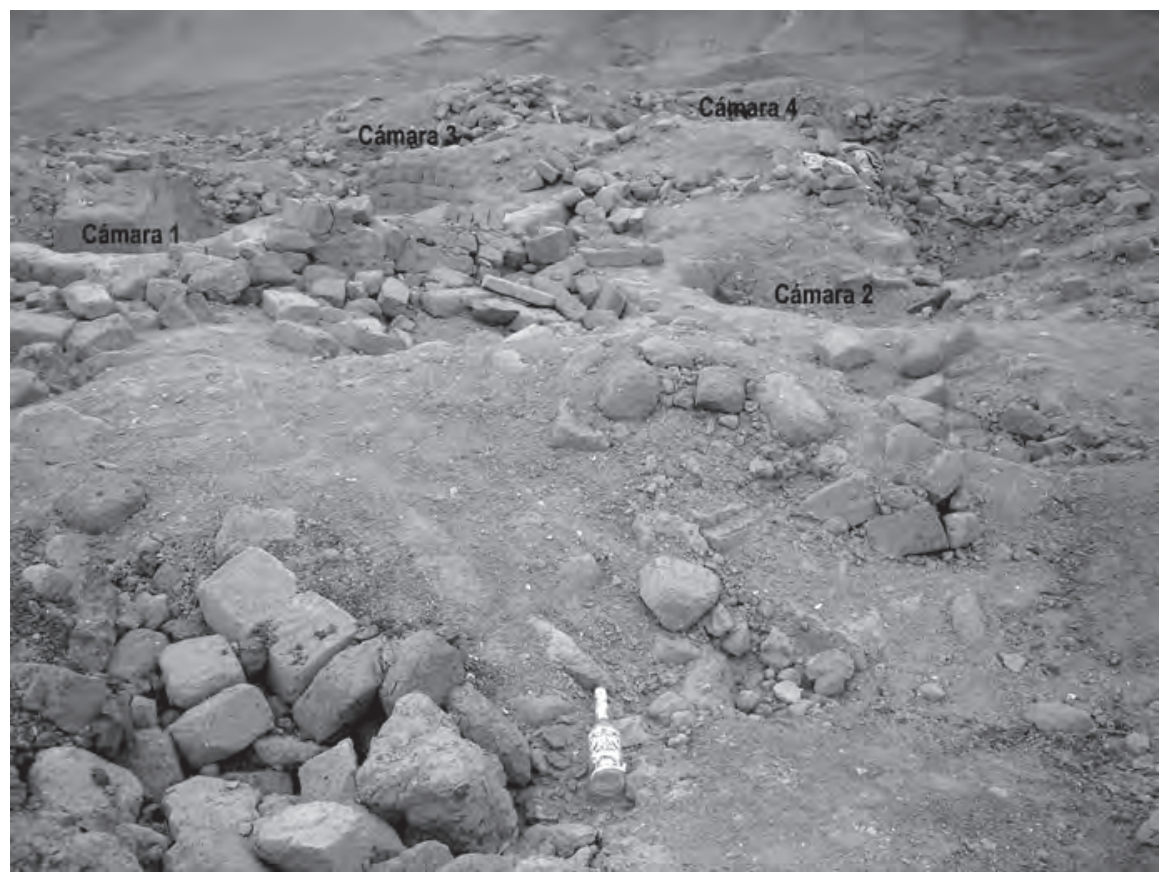

Figura 9. Cámaras funerarias.

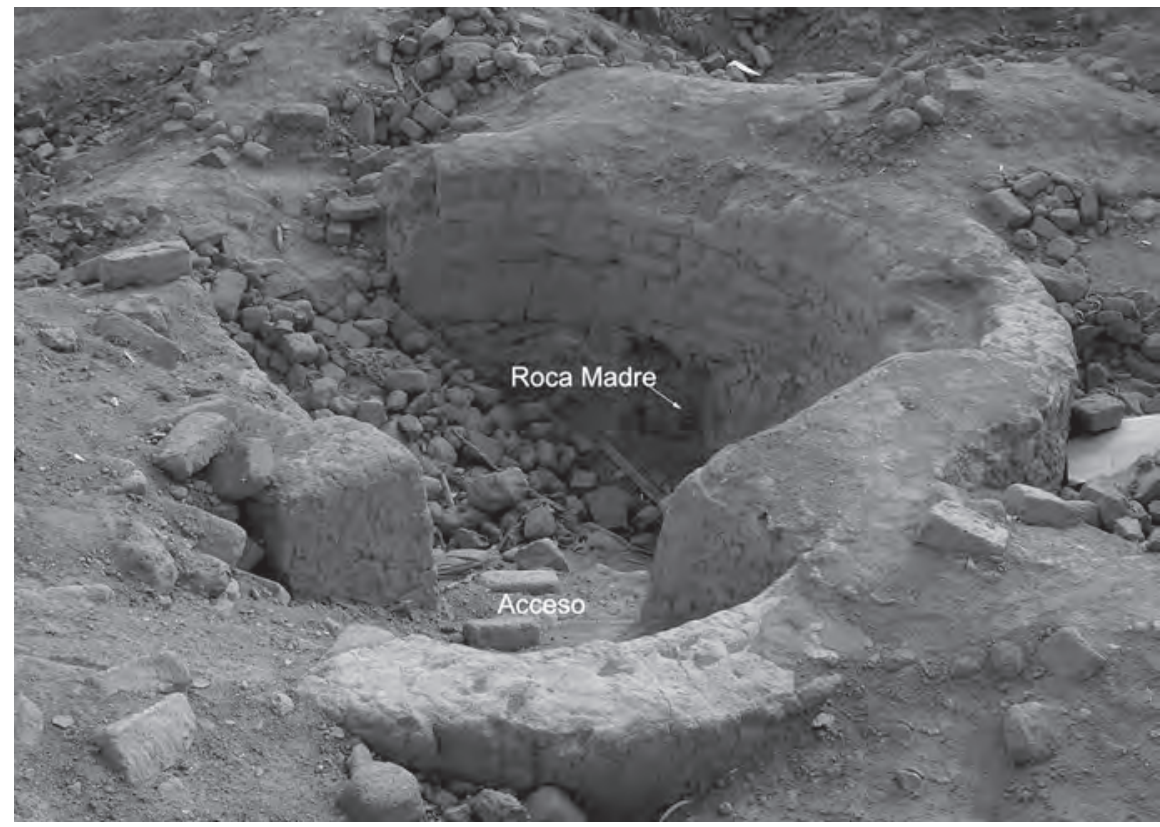

Figura 10. Cámaras funerarias en detalle.

Arriaga «[...] los cuerpos muertos sienten, comen y beben y que están [...] con más descanso en sus machais y sepulturas en los campos donde no están enterrados, sino en unas bovedillas y cuevas o casitas pequeñas[...] ([1621] 1968: 220), serían sepulcros abiertos (Gil 2009: 62) que articulaban a la sociedad, donde «los mallquis actuarán como centro motor del grupo de parentesco. El acceso a las cámaras y evidencia de cubiertas refuerza la posibilidad de momias enterradas en este contexto religioso y asociado a 
una plaza principal, estos ancestros fueron enterrados en un contexto público, para Olivier Le Guen (2008), corresponderían a ancestros colectivos con ceremoniales que concentraba a la comunidad para realizar el culto a los antepasados a través de las prácticas rituales donde «se agrupan en la plaza por clanes y parcialidades y sacan los cuerpos momificados de sus ancestros, llamados munaos en las tierras bajas y malquis en la sierra, junto con los cuerpos robados de la iglesia, y da la impresión de que los vivos y los muertos hubieran llegado al juicio. También sacan sus huacas personales, y los sacerdotes más destacados sacan las huacas que veneran en común. Se les preparan ofrendas y se les exhiben las vestimentas que se utilizan en las fiestas y los plumajes con que adornan, las vasijas, cántaros y vasos usados para hacer y tomar chicha que se ofrecen a las huacas[...]» (Arriaga (1968 [1621]: 19). Las escalinatas, de las cámaras, son evidencia del mantenimiento y culto que debió efectuarse en esta plataforma a cuerpos de los ancestros que formaron parte de la vida diaria y mantenimiento del orden social.

Los adobes usados en la construcción del templo se caracterizan por ser rectangulares elaborados con molde de madera y en menor cantidad en molde de carricillo, miden $37 \mathrm{~cm}$ de largo, $14 \mathrm{~cm}$ de ancho y $9 \mathrm{~cm}$ de espesor, además se han construido algunos muros de piedra canteada extraída de los cerros colindantes.

Para ingresar a la plaza principal, se observa una escalinata localizada en el lado sur oeste, al alcanzar el nivel de la plaza se encuentra un pequeño ambiente rectangular en muy mal estado de conservación.

Un dato adicional mencionado por el escritor Ernesto Reyna, señala que en el pequeño afloramiento rocoso al oeste de la plataforma los viajeros se quitaban el sombrero y al llegar al cerrito de la Huaca de el Campanario echaban ofrendas de piedra en la apacheta (Reyna 2013: 58). Considerando la disposición de la arquitectura, su tratamiento y acabado, las tumbas y los relieves muestran la sacralidad del lugar, se trata de un lugar destinado al culto y adoración de ancestros.

\section{ARQUITECTURA ADMINISTRATIVA Y RESIDENCIAL EN CERRO CAMPANARIO}

Se localiza en el lado sur del complejo y se distribuye en todo el cerro con la mayor concentración se en la ladera norte, aquí se delimitaron cinco conjuntos (Fig. 11).

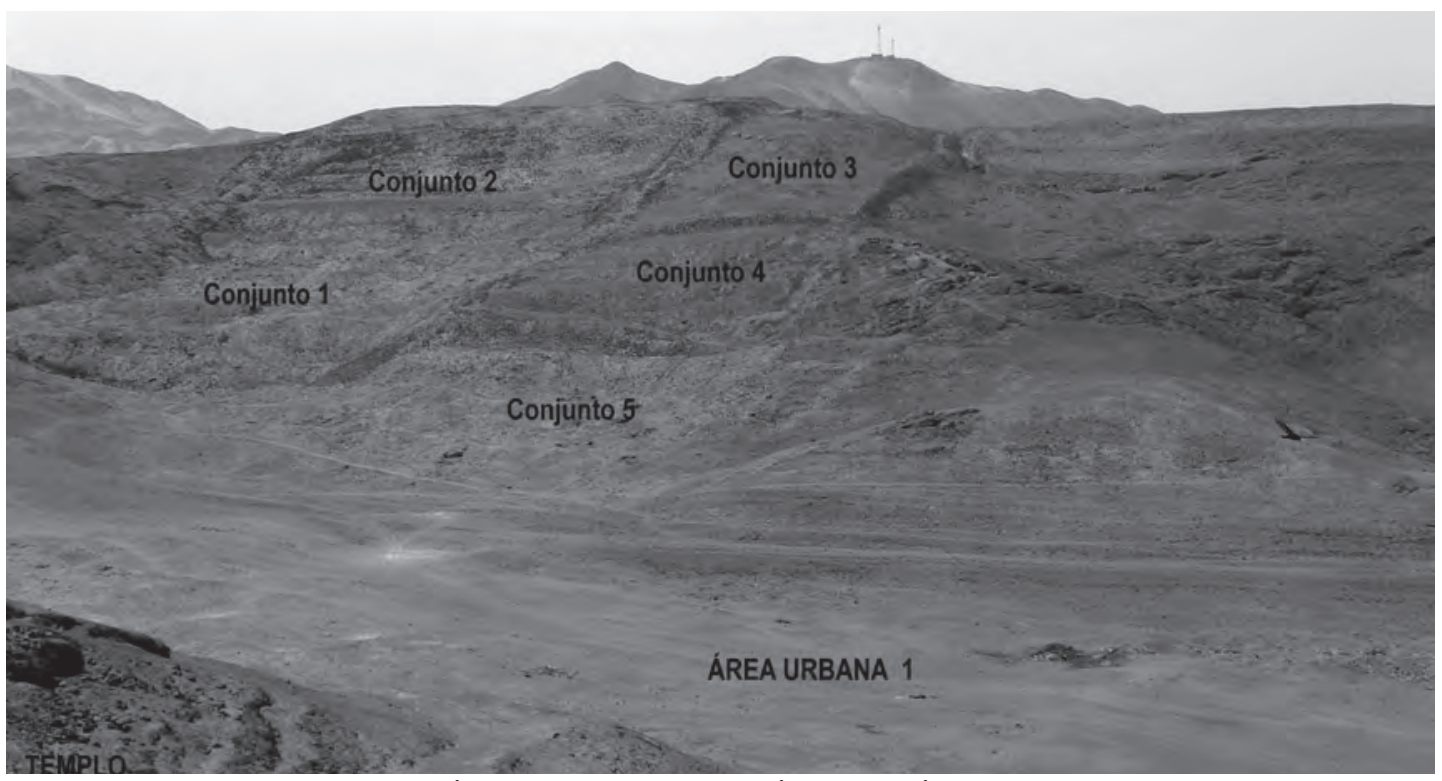

Figura 11. Cerro Campanario y sus conjuntos. 
El Conjunto 1 presenta terrazas que van ascendiendo hacia la cima del cerro; en la parte central de éstas se localiza una terraza independiente de cuatro niveles con una rampa y hacia el lado este un pequeño espacio que forma parte de esta estructura que debió funcionar como el lugar con la actividad más importante para el personaje de mayor estatus del sitio. Este conjunto muestra en su superficie gran cantidad de alimentos como paltas, restos malacológicos, maíz, semillas de frutales entre otros no identificados, además de gran cantidad de fragmentos de cerámica en su mayoría conformada por cuencos, grandes vasos, tipo kero y ollas.

La cima del cerro o Conjunto 2 destaca por una pequeña plataforma construida de piedra (Fig. 12) desde donde se puede observar todo el valle bajo. Varios ambientes se asocian a esta estructura en ambas laderas, además de restos de alimentos y cerámica. En un pozo de huaquero hemos registrado la presencia de dos pisos superpuestos, el primero se asocia a un muro de piedra y está relleno por una gran cantidad de fragmentos de adobes, que debieron corresponder a parte del muro colapsado (Fig. 13). Los Conjuntos 3 y 4 no tienen arquitectura en su interior.

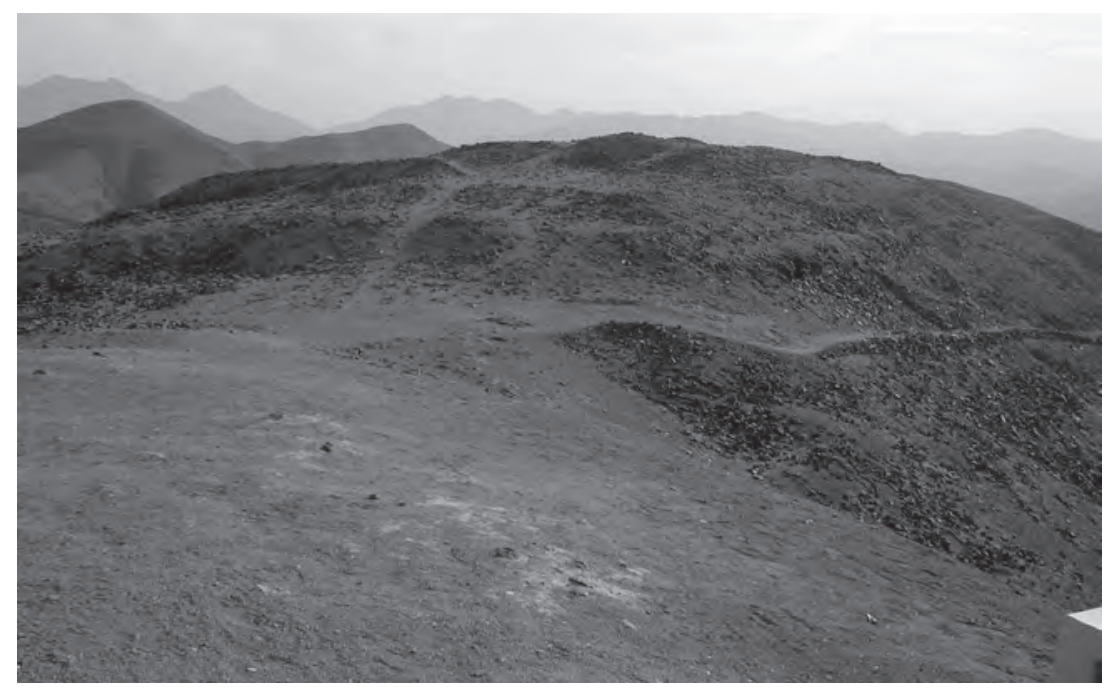

Figura 12. Conjunto 2.

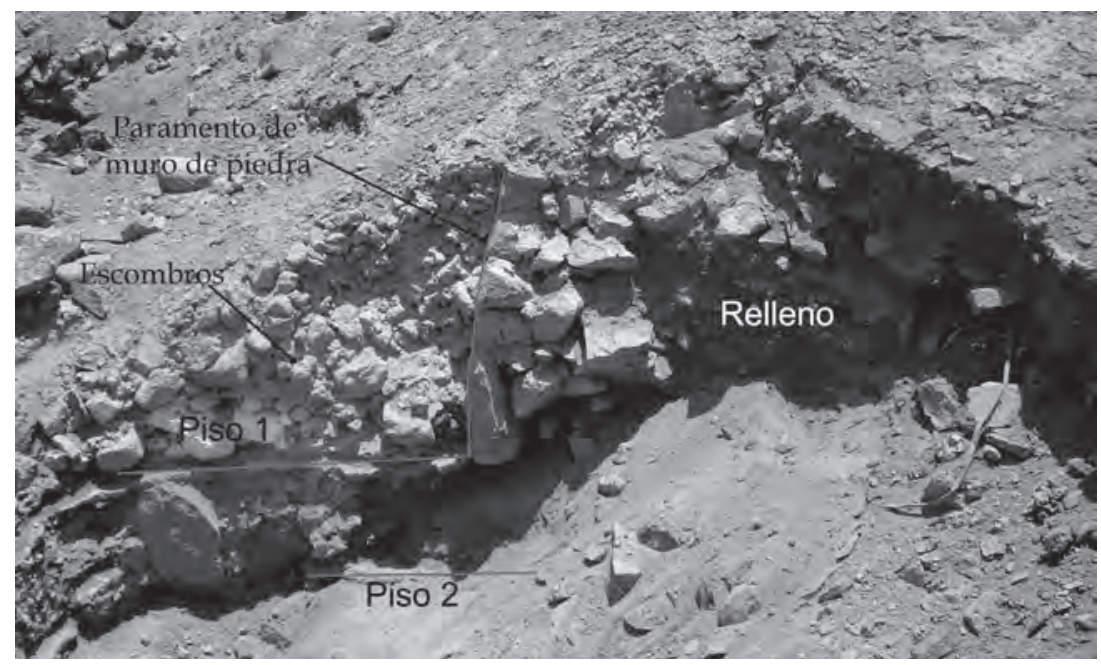

Figura 13. Perfil en el Conjunto 2. 
El Conjunto 5 presenta muros exclusivamente de adobes, esto lo diferencia del resto de los conjuntos, escaza cerámica se halla en la superficie, los muros presentan finos acabados. Se han hallado evidencias de relieves representando aves y figuras geométricas (Fig. 14 a, b y c), estas esculturas han sido elaboradas en adobes donde la arcilla que se empleó fue mucho más plástica, por la ausencia de temperante, se trata de arcilla primaria.

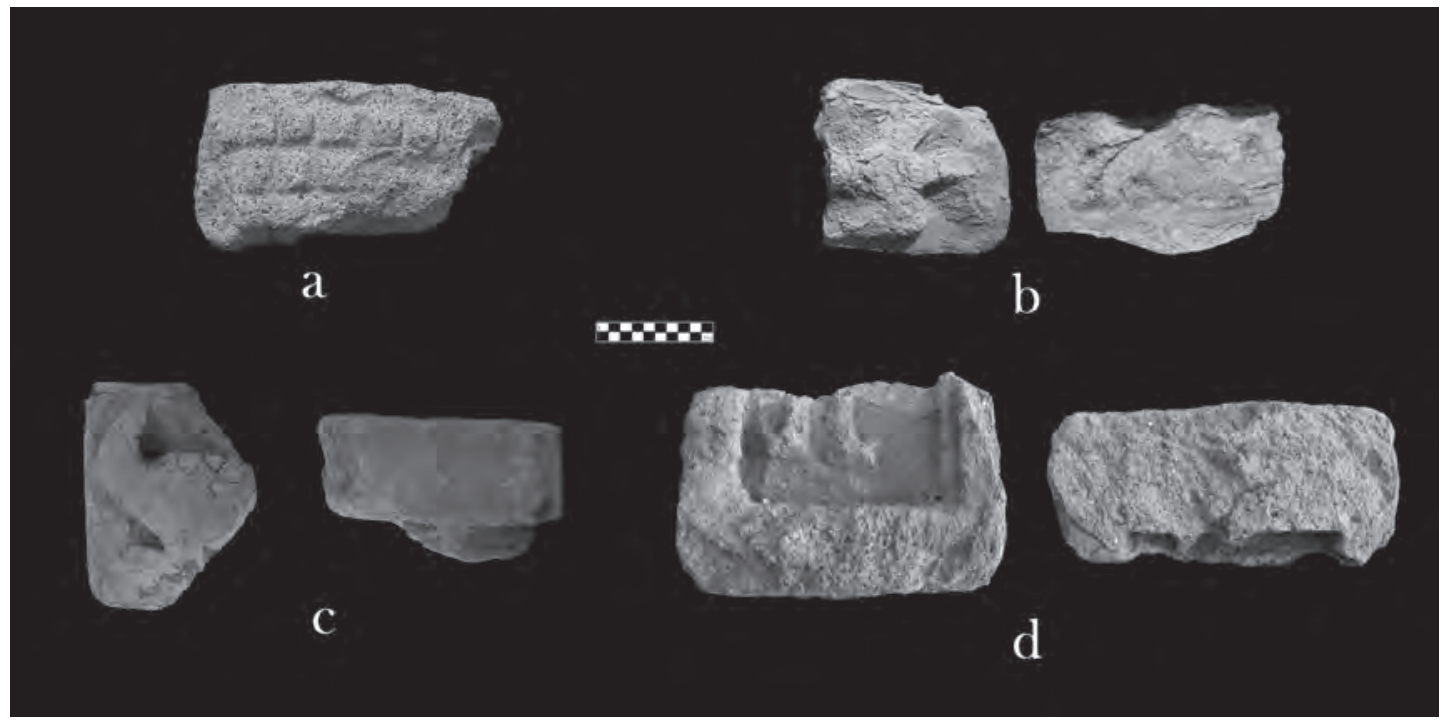

Figura 14. Relieves hallados en el conjunto 5.

El muro este que delimita los conjuntos 1 y 2, se conforma de piedras con un solo paramento, el interior fue rellenado con grumos, abobes fragmentados y completos, tierra y piedras; el soporte en su extremo opuesto fue la roca madre que junto al paramento este formaron un encajonamiento (Fig. 15), al terminar de rellenarse todo el interior se continuó con la construcción del muro mediante el uso de adobes de las mismas dimensiones, forma y componentes de los descritos para el templo.

La arquitectura se caracteriza por el uso de piedra y adobe, generalmente en las partes bajas se intensificó el uso de piedras y en las partes medias y altas se complementó con adobes como se ha reportado para el sitio de Purgatorio (Vogel y Pacifico 2011: 374). En este sector del complejo Campanario se ha registrado el uso de materiales vegetales para lograr una mayor estabilidad de los rellenos que conformarían las bases para pisos o áreas de tránsito. Los elementos diagnósticos en cerro Campanario indicarían la función como administrativa y residencial.

\section{SECTOR CON ARQUITECTURA URBANA}

Hemos identificado cuatro áreas con arquitectura urbana (Fig. 3). El Área Urbana 1, se sitúa entre la Plataforma cercada por tres muros concéntricos y el cerro Campanario (Fig. 16), es la de mayor tamaño $327 \mathrm{~m}$ de largo (eje este-oeste) por $92 \mathrm{~m}$ ancho (eje norte-sur), su diseño arquitectónico se conforma de cuartos, callejones, patios y plazas, construidos con adobes que miden 0,37 m de largo, $0,14 \mathrm{~m}$ de ancho y 0,09 $\mathrm{m}$ de espesor y piedra canteada que generalmente fue usada en la base de algunos muros, por los finos acabados de los muros y la ubicación privilegiada se trataría de residencias de elite.

Al norte de la zona urbana y este de la plataforma, en lo que forma parte de una pequeña quebrada se observan restos de quema, gran cantidad de desperdicios de alimentos y fragmentos de tinajas, evidencias que indican actividades de preparación de alimentos en grandes cantidades. 


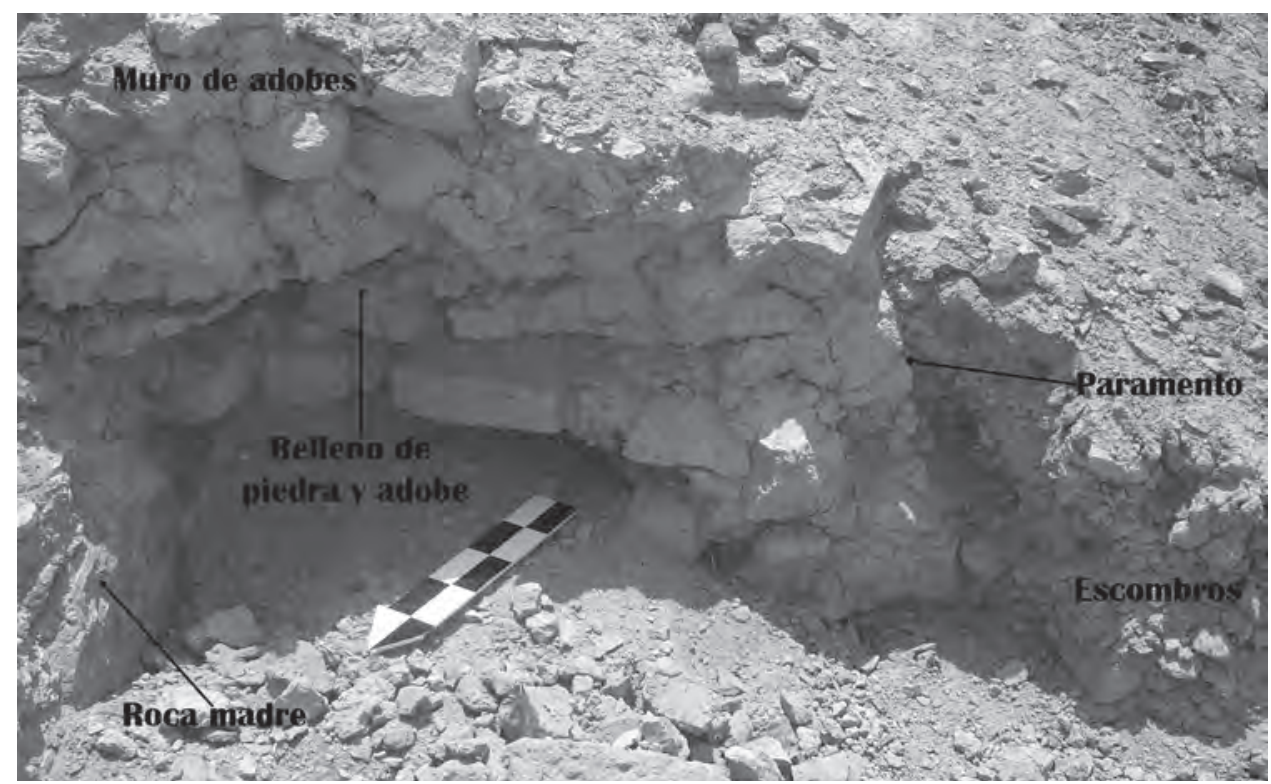

Figura 15. Perfil del muro este de los conjuntos 1 y 2.

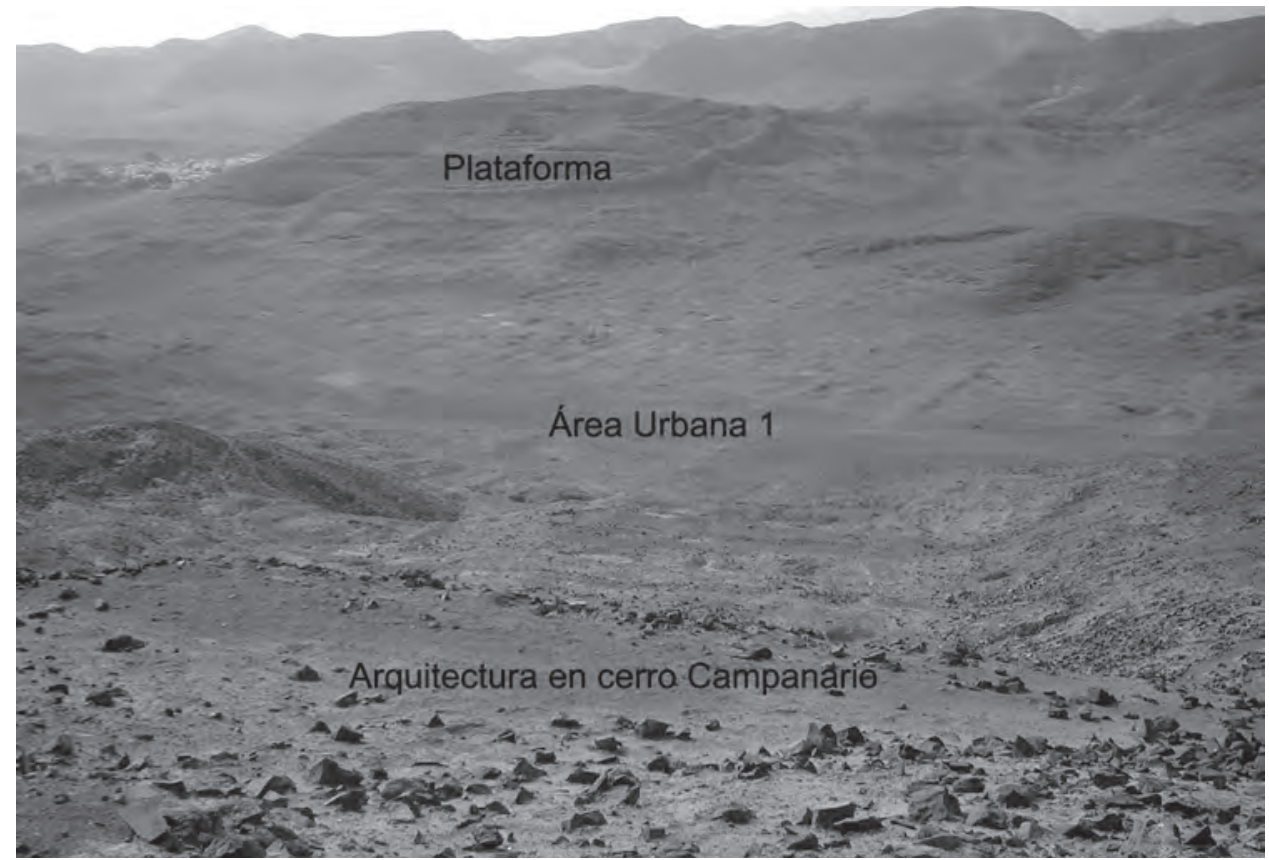

Figura 16. Área urbana 1.

El Área Urbana 2, se localiza al noroeste en la parte baja (Fig. 17), junto a la plataforma de un aterrazamiento que mide $85 \mathrm{~m}$ (de norte a sur) por $60 \mathrm{~m}$. Por su cercanía y comunicación a la plataforma, sus materiales constructivos con adobes y finos enlucidos así como, su ubicación más elevada sobre el resto de arquitectura, $33 \mathrm{msnm}$. Seria de alto estatus. En su superficie se distinguen una variedad de ambientes construidos con muros, hacia el oeste tres desniveles conforman pequeños espacios 


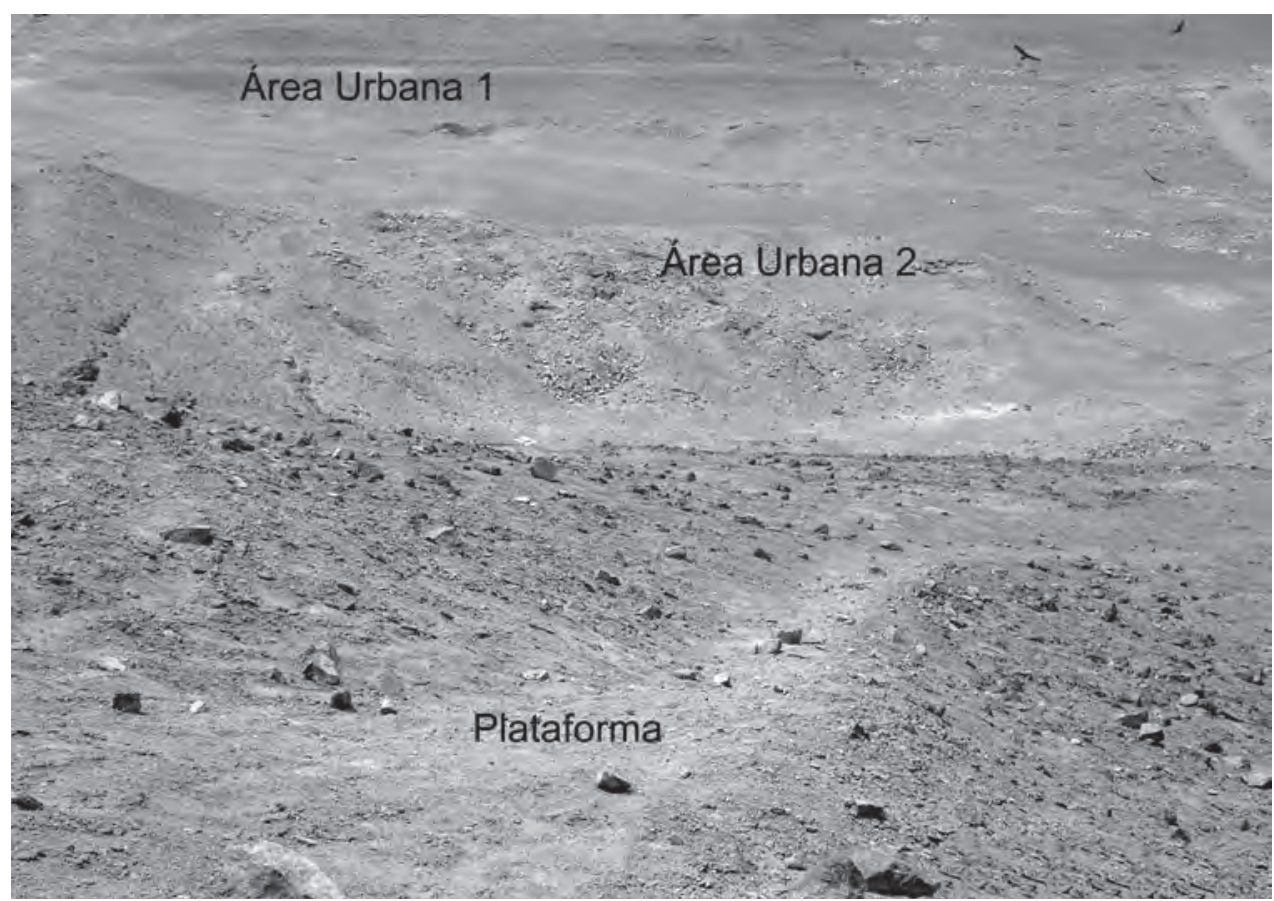

Figura 17. Área urbana 2.

amplios que quizás fueron la antesala relacionada a las actividades de esta área, también se puede ver gran cantidad de improntas de techo, y parte del tramado que conformó la base de la cubierta, identificada como caña brava y caña bambú; un tercer elemento diagnóstico asociado es la presencia de pintura mural de color rojo, amarillo y blanco. Muros de tapia se presentan unos metros más al oeste, quizás corresponden a una ocupación posterior.

El Área Urbana 3, se ubica en una pequeña quebrada al norte del templo; la arquitectura se encuentra totalmente destruida por maquinaria que extrajo materiales de construcción, parte de esta área fue también alterada por un cementerio chino donde antiguamente celebraban sus ceremonias preparando cerdos horneados y que participaba todo el pueblo.

La cuarta área tiene las dimensiones de 100 x 100 m, correspondería a personas de bajo estatus ubicados en la ladera suroeste de cerro Campanario donde se observa abundantes restos malacológicos y cerámica doméstica, además de cañas enterradas, alineadas con amarres que debieron ser parte de la estructura de quincha, una estructura de adobe en muy mal estado de conservación, se encuentra en esta área, aquí se registro un adobe fragmentado que presentó parte de un relieve antropomorfo (Fig. 14d).

\section{LOS DEPÓSITOS}

Se emplazan en la ladera noroeste del cerro Campanario junto al cementerio «Viejo» o San Lorenzo, es una construcción rectangular que se comunica hacia una estructura circular, el muro delimitante a los lados este y oeste mide $0,80 \mathrm{~m}$ de ancho, y al sur $60 \mathrm{~m}$. Dentro de la estructura rectangular se diseñaron dos bloques de depósitos (Figs. 18 y 19), que fueron divididos por un callejón central que se orienta de norte a sur, en el bloque oeste se construyeron diez depósitos que miden 8,50 m de largo (eje este oeste) por un ancho que varía entre 6,30 m hasta 7,80 m, el acceso a este bloque de depósitos se realizaba por el extremo norte del muro este, donde se diseñó un vano de $1 \mathrm{~m}$ de ancho; en el bloque este se encuentran 


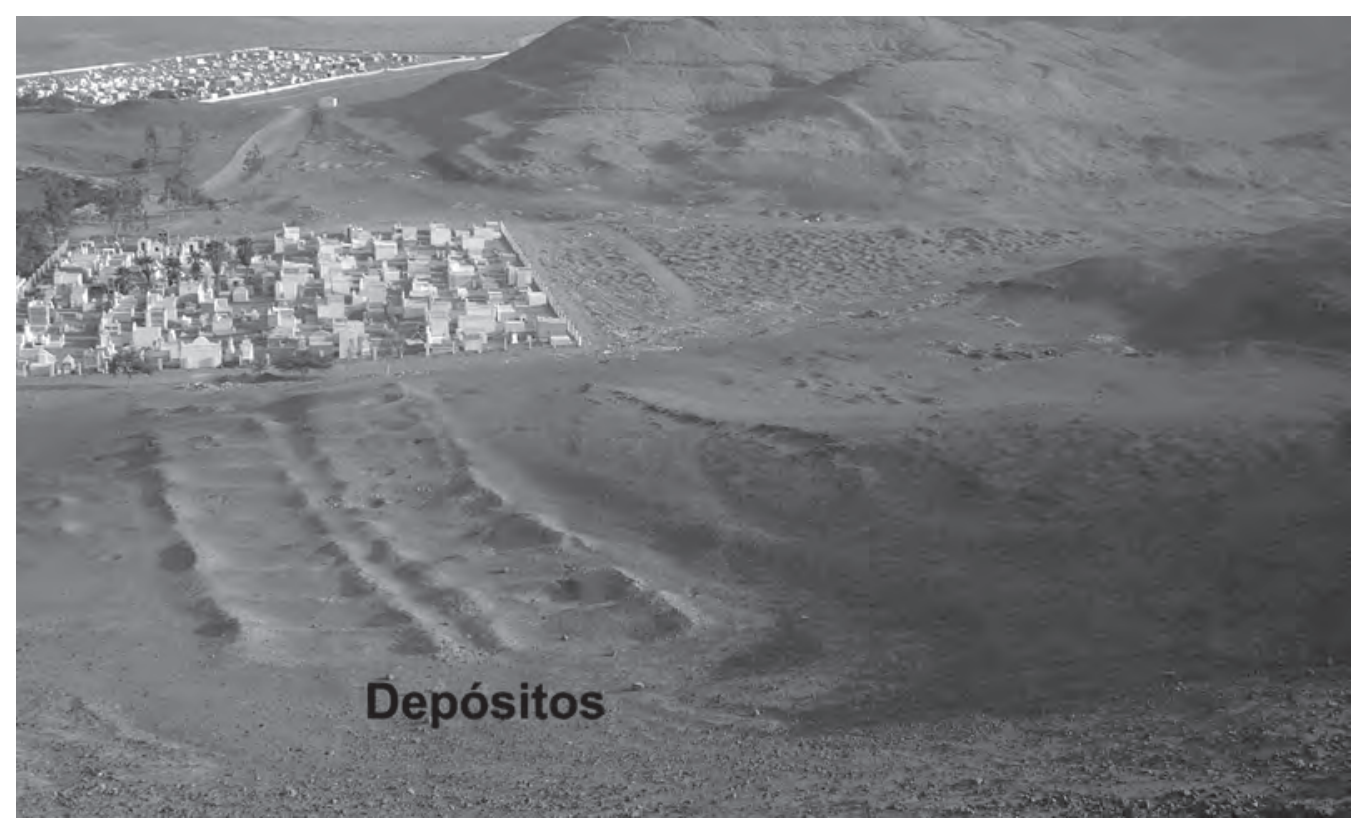

Figura 18. Depósitos.
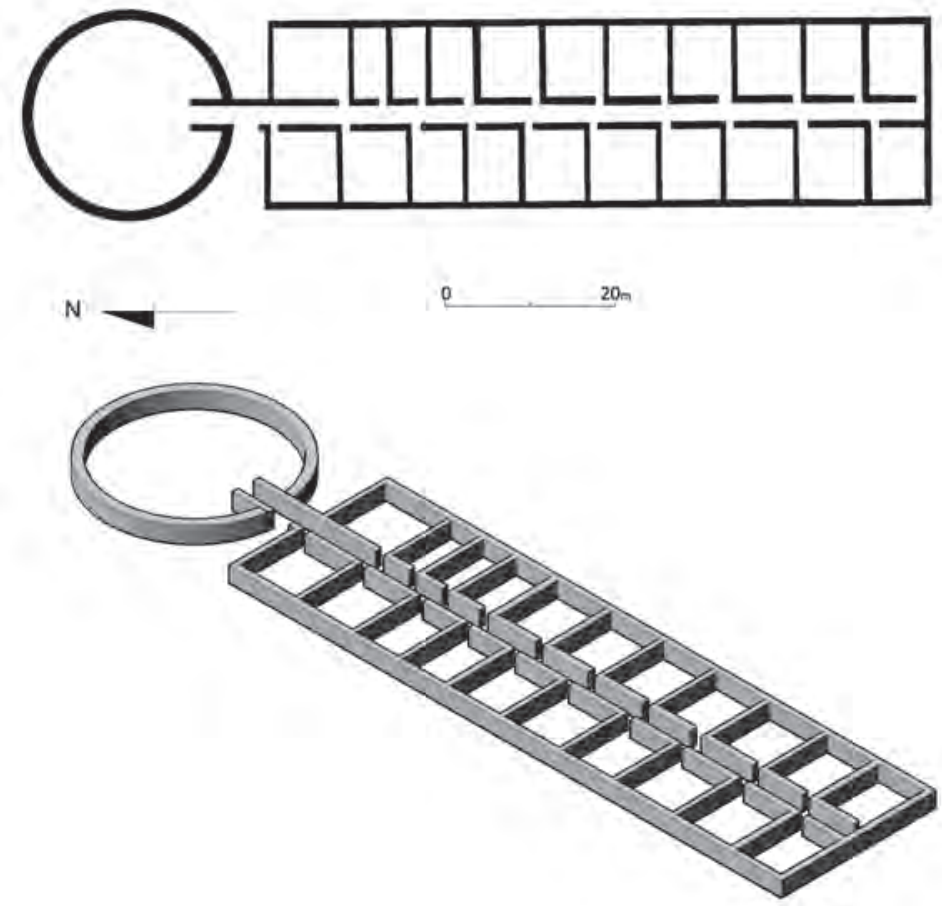

Figura 19. Vistas de planta e isométrica de los depósitos. Dibujo de José Gómez. 
once depósitos con medidas de 8,50 m de largo (eje este oeste) y un ancho variable desde $9 \mathrm{~m}$ a 6,30 $\mathrm{m}$ excepto dos depósitos muy cercanos al ambiente circular que tienen un ancho de 3,80 $\mathrm{m}$ el acceso es opuesto en ubicación a los depósitos del bloque oeste, se realizaba por el extremo sur del muro oeste, el vano medía $1 \mathrm{~m}$ de ancho. El callejón divisorio se inicia en una estructura circular que mide $23 \mathrm{~m}$ de diámetro y su muro 0,80 $\mathrm{m}$ de espesor. Se emplaza a una altura de $33 \mathrm{msnm}$.

La ubicación de los depósitos alejados y a una altura mayor con respecto al área urbana se debió al cuidado que se tenía con los bienes de uso y consumo, en estos radicaba el poder político ya que por medio de la reciprocidad (donde se brindaba bebidas y comidas a cambio de fuerza de trabajo y por ello la necesidad de tener los depósitos llenos de productos) se lograba la ejecución de obras masivas, además con su ubicación se mantenía fuera del alcance de plagas, insectos, hongos y roedores, la altura para evitar posibles inundaciones y finalmente la excelente temperatura que se concentra en esta parte del sitio, donde los vientos son indirectos y mantenían conservados los bienes.

\section{LOS CEMENTERIOS}

El complejo presenta tres cementerios (Figs. 2 y 3), El cementerio A, localizado en la falda este del cerro Santo Domingo, a $650 \mathrm{~m}$ al noroeste del templo, se encuentra intensamente saqueado, mide 380 $\mathrm{m}$ en su eje norte-sur y $120 \mathrm{~m}$ en el eje este-oeste, la mayoría de tumbas son fosas simples donde se colocaron los cuerpos con sus ofrendas, aunque hemos fotografiado algunos adobes pintados en rojo y con evidencia de enlucido, por lo tanto, algunas cámaras también debieron ser parte de este cementerio. Gran cantidad de restos óseos se encuentran en la superficie, muchos de estos aún están en proceso de descomposición. Dos estructuras (Fig. 1) se localizan al norte del cementerio, la estructura 1, la más alejada del cementerio está intacta y se conforma de tres terrazas; la estructura 2 (que en 1940, época de la peste bubónica, fue reutilizada como casa de recuperación para los enfermos) está totalmente destruida y se asocia a una gruesa capa de excremento de animal y a materiales vegetales donde se aprecia caña brava que podrían corresponder a una cubierta, no sabemos si el excremento es prehispánico o de los pastores trashumantes que vienen desde el pueblo de Pararín. Alrededor de este ambiente se observa la presencia de ceniza, áreas de quema, fragmentos de cerámica y algunos moldes de arcilla.

El cementerio B se ubica en el extremo oeste del área urbana 1, limitando con un cementerio actual, aquí observamos adobes que parecen ser parte de encajonamientos o arquitectura, se registraron restos de cobre, parecen tratarse de tumbas intrusivas.

El cementerio C, hemos observado encajonamientos rectangulares en la parte baja al norte del templo, en la quebrada que le corresponde al área urbana 3, se trata de encajonamientos que miden 1,61 m (en su eje norte sur) y 1,65 m (en su eje este oeste) y que tiene un enlucido muy fino con arcilla, algunos fragmentos de cerámica se podían observar alrededor de estos.

\section{El Complejo Campanario: un Centro administrativo Y RELIGIOSO DEL VALLE DE HUARMEY}

La monumentalidad y diversificación de áreas de actividad hacen de Campanario el sitio más complejo y monumental del valle de Huarmey asociado a cerámica Casma. Se plantea como propuesta de investigación a ser definida mediante mayores estudios que la población de Campanario dominó todo el valle de Huarmey desde Manache, hasta el valle medio alcanzando los pueblos de Huamba Alta y Huiña donde confluyen los ríos Aija y Malvas que forman el río Huarmey.

Para establecer su dominio instalaron sitios que controlaban la producción y el transporte (Figs. 20 y 21), el sitio principal desde donde se planificaba y dirigía todo el gobierno fue el complejo Campanario, mediante el sistema de reciprocidad, intercambio y sistemas laborales tipo ayni o minka se mantenía a la clase gobernante, a los especialistas y la burocracia. 


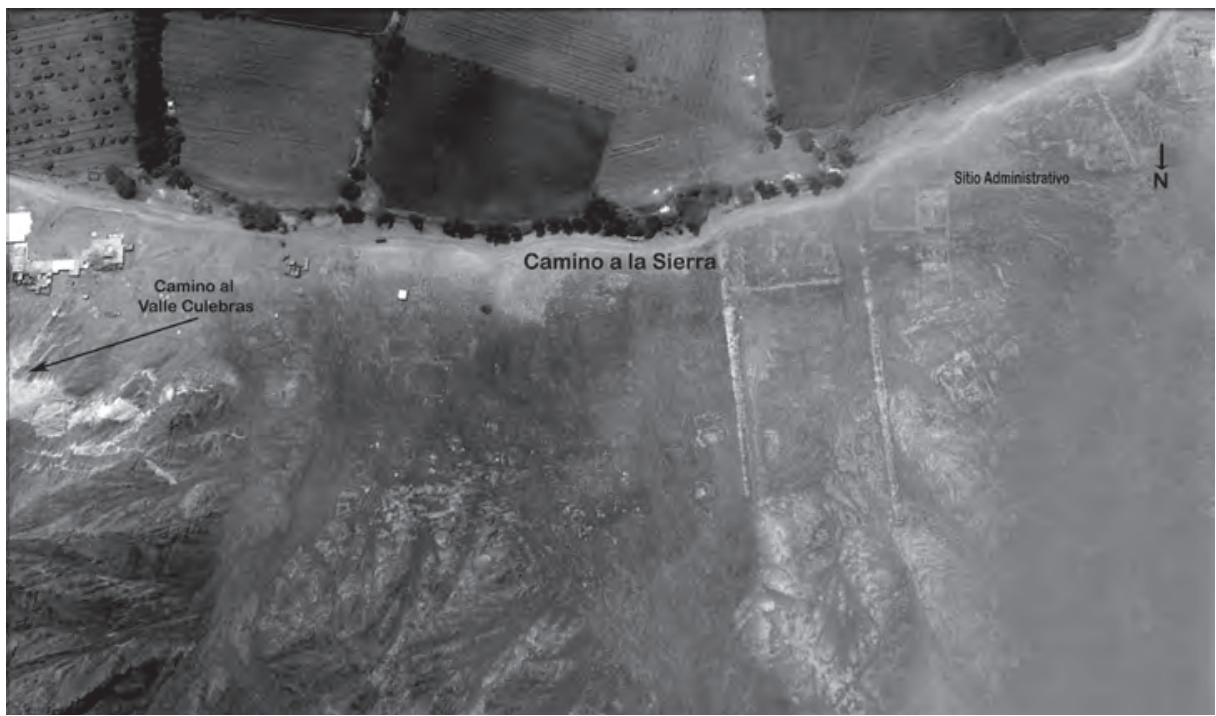

Figura 20. Fotografia de sitio de control en Tayca, margen derecha. (Google Earth 2013).

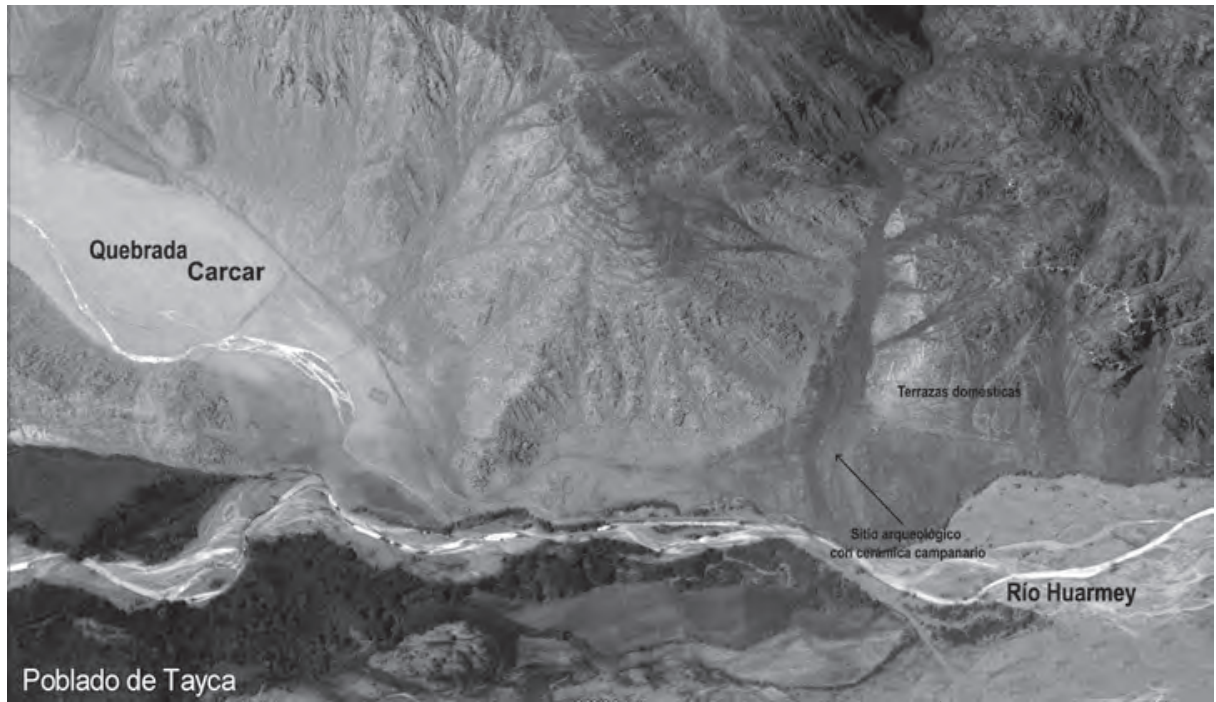

Figura 21. Fotografia aera de Tayca, sitio de control margen izquierda. (Google Earth 2013).

Todo el complejo se organizó para desarrollar principalmente labores administrativas y religiosas; sin embargo, Huarmey no es un valle extenso en terrenos agrícolas, en la actualidad 7.479,67 ha de superficie agrícola (INEI, III Censo Agropecuario 1994), por lo tanto, aunque se debió explotar al máximo su estrecho valle, no obtenía abundante producción, además el valle no tiene agua constante durante todo el año; entonces, ¿Por qué resultaba estratégico gobernar y administrar el valle de Huarmey?. Cuatro recursos hacían de este valle un sitio importante, el primero es la presencia del mar que hasta la actualidad es uno de los más ricos de la costa; por su conformación geológica donde abundan peñas e islotes han creado las condiciones para que abunde aquí una comunidad biológica que ha generado la variada ictiofauna complementada con mariscos, por lo que se debió contar con grupos de especialistas dedicados a tiempo completo a la pesca o extracción de mariscos (como existen en la actualidad) y la élite administró lo obtenido y otros especialistas se dedicaron a su redistri- 
bución, transporte e intercambio con diversos pisos ecológicos; este modelo hizo que los Campanario pudieran obtener los bienes (en especial agrícolas y suntuarios) para complementar su déficit y así tener los recursos necesarios para satisfacer los requerimientos de reciprocidad y contar con mano de obra disponible.

El segundo recurso está referido a que el valle de Huarmey posee una ruta de transporte vertical que conduce a la sierra y selva, es corta y menos abrupta, así que debió ser una ruta constante para el transporte y comercio de artículos de la costa hacia la sierra y selva y viceversa, en la actualidad aún se pueden observar la infinidad de caminos de herradura que usando las quebradas o por la cima de los cerros se encuentran corredores hacia la sierra, situación similar encontramos en las rutas horizontales norte-sur, por lo que su administración brindó poder a los gobernantes, este tránsito existió y se controló desde épocas tempranas, por ello los montículos precerámicos y formativos registrados en el valle de Huarmey se sitúan en los accesos a las quebradas como por ejemplo: la plataforma de esquinas curvas en el sector El Lecheral, las dos plataformas en la quebrada Mal Paso y el sitio de Pedregal en la quebrada del mismo nombre (Bonavia 1982).

Un ejemplo moderno, de comunicación vertical es el pastoreo trashumante, donde miles de cabezas de ganado rotan durante todo el año entre la costa y la sierra en busca de alimento y agua, a estas personas se les conoce como «Pararinos», haciendo referencia al distrito de Pararín situado a 3250 msnm, perteneciente a la provincia de Recuay, la comunidad es propietaria de todo el ganado y por un año se le asigna una cantidad determinada (aproximadamente 200 cabezas) a cada familia, hemos registrado alrededor de tres familias recorriendo diversos sembríos que alquilan hectáreas con chala, nombre que se le da a la planta de maíz que se corta y comercializa antes que produzca el choclo y que usa exclusivamente para forraje, los meses que arriban a la costa es Noviembre a Febrero; de igual manera otros pastores «bajan» al valle Fortaleza, el ganado es designado por especie a algunos les tocará ganado vacuno, a otros ganado caprino (Observación participante efectuada por los autores, en el poblado de Tayca 12/02/2011)

El tercer recurso se trató de canteras de cuarzo y minerales que se focalizan en el área de Barbacay (en la actualidad mineros informales extraen oro) donde se observa arquitectura temprana y tardía con extensas áreas de quema y canteras de cuarzo (Fig. 22), condiciones similares se presentan en el valle de Culebras.

La cuarta evidencia que por este valle un sitio de peregrinaciones cíclicas se sustenta en el hallazgo de la asociación de geoglifos (Fig. 23), petroglifos y estructuras rituales en el Cerro Copa de Sombrero o Toledo (Zavaleta et al. 2009: 42-45; Zapata 2012), cerca al pueblo de María Cristina, en el valle medio de Huarmey; se trata de un área donde debió converger una importante cantidad de personas que participaron en rituales que continuaron hasta épocas tardías. Quizás estamos frente a un oráculo o el sitio religioso más importante del valle que tuvo vigencia hasta épocas tardías y que concentro alrededor de este cerro varias actividades que han quedado evidenciadas en una variedad de restos materiales, así tenemos geoglifos, en las laderas este y oeste asociados a estructuras, acumulaciones de piedra imitando muros en la ladera nor oeste en un sector específico que los pobladores denominan Lacrao, estos muros paralelos ascienden hacia la cima, en donde se encuentra una senda que conduce a un espacio con gran cantidad de piedras y diversos restos de arquitectura que no han sido aún investigados, además de la asociación a una ruta de constante movilización de personas y ganado en la quebrada Mal Paso, todo el contexto arqueológico indica un lugar donde se estableció un contacto con la naturaleza y lo sobrenatural conformando una institución que proporcionó información que no sólo debe haberse tratado de presagios sino que la conformación morfológica del cerro podía haberse utilizado como un calendario para determinar cambios estacionales y otros elementos de control social que le dio el valor, confiriéndole a esta área como «[...] deidades tutelares personificadas en diversos elementos de la naturaleza, principalmente montañas, que controlan los fenómenos meteorológicos y la vida de las personas en las aldeas vecinas. Se les rendía culto y propiciaban 


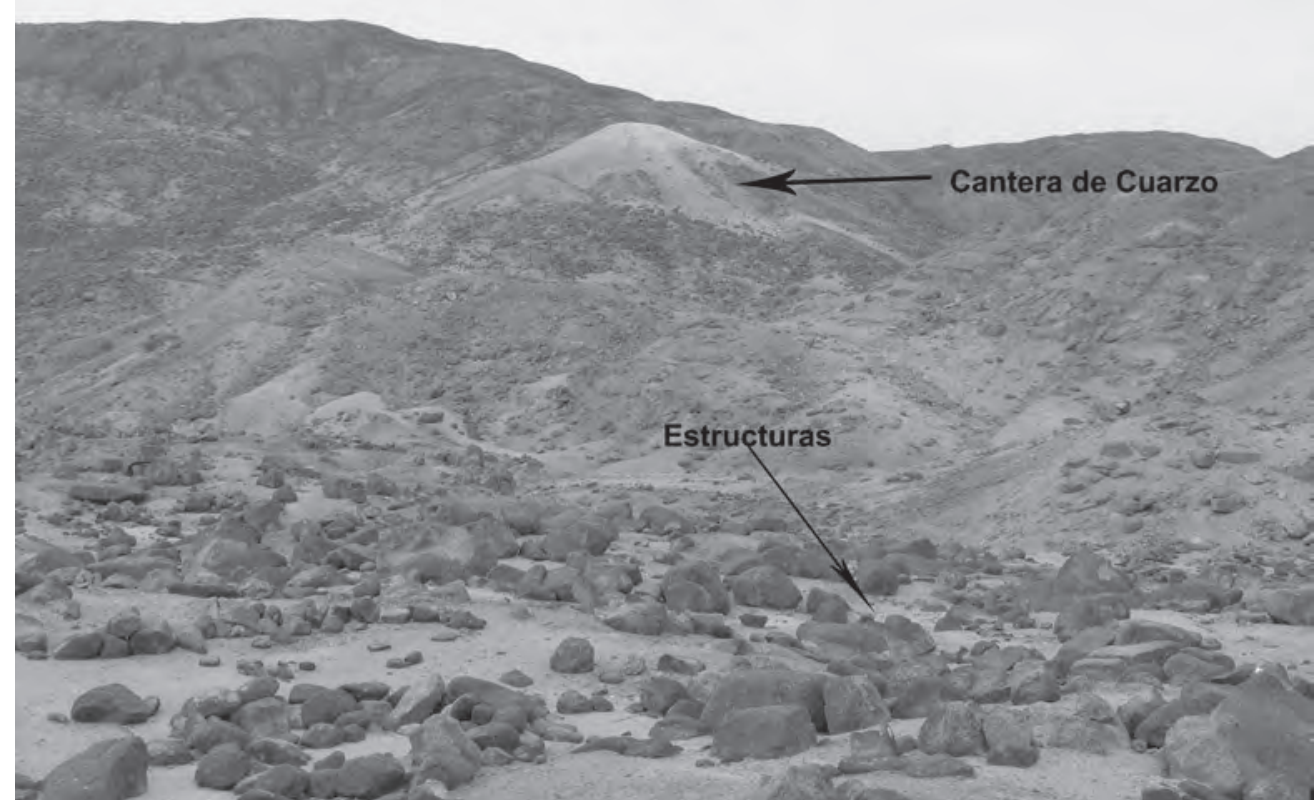

Figura 22. Arquitectura y presencia de cuarzo en Barbacay.

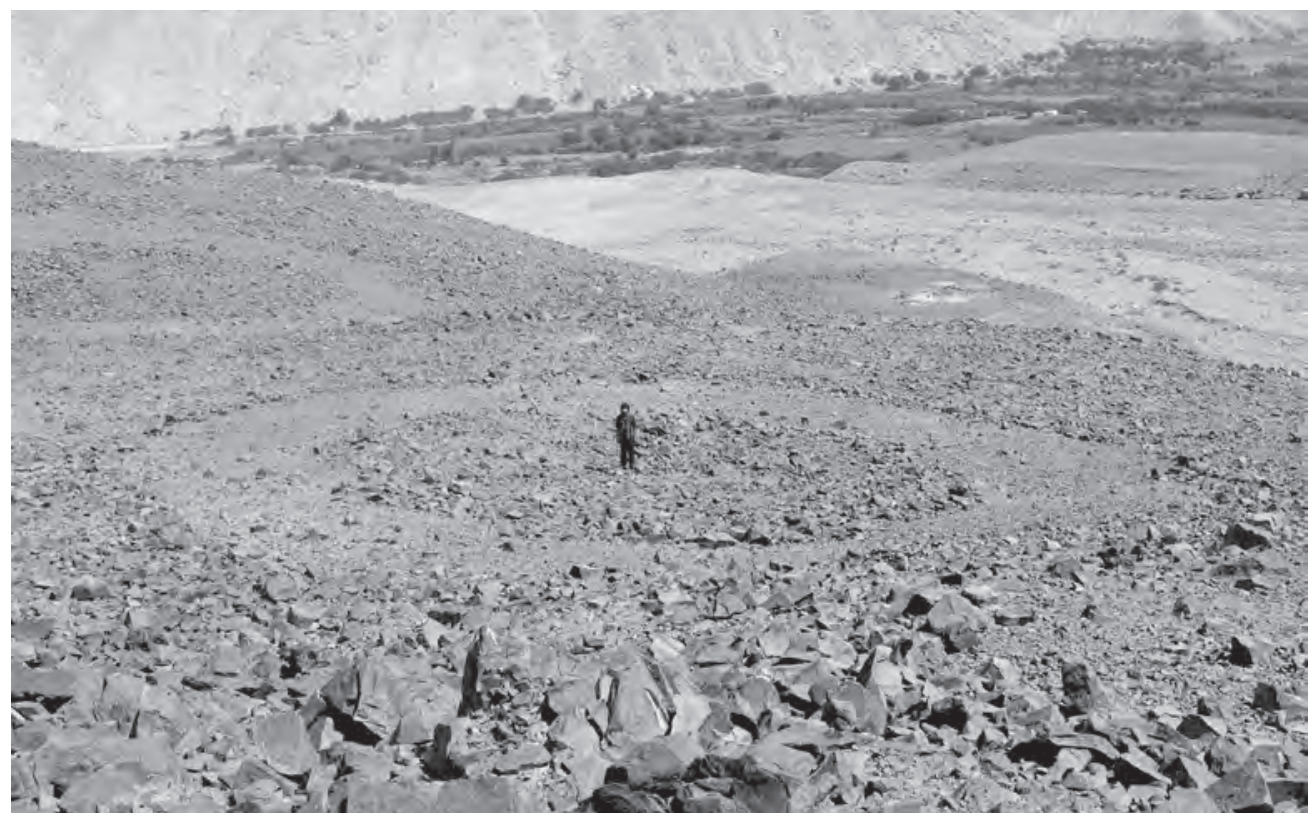

Figura 23. Geoglifos lado este quebrada 1.

ofrendas acorde a las necesidades y exigencias del apu» (Vitry 2008:4) pero este sitio no sólo sirvió para la religiosidad «sino que constituyeron formidables instrumentos de legitimación del poder e influencia política» (Curatola y Ziólkowski 2008). La ubicación formidable, de Cerro Toledo, junto a las dos vías principales de comunicación la quebrada Mal Paso y el camino hacia la sierra, la presencia del río Huarmey y su configuración geomorfológica y monumentalidad hicieron de este sitio un emblema de culto y manejo social. 
Al abandonarse el sitio del Castillo de Huarmey, en el Horizonte Medio, el Complejo Campanario alcanza la posición más alta de dominio en todo el valle, construyendo diversos sitios de control en las áreas de mayor actividad económica y de tránsito, prueba de esta evidencia es la cerámica y la arquitectura asociada a esta, distribuida en todo el valle que hemos podido registrar desde el valle Bajo hasta el pueblo de Huiña. El Complejo Campanario fue planificado y construido para controlar toda la actividad económica del valle concentrando aquí una élite que gobernaba, administraba y residía. Se implementó una red jerarquizada de supervisores o administradores que fueron instalados en centros administrativos secundarios, distribuidos en todo el valle, para el control de la producción, tributos y movilización de los bienes.

\section{LAS FORMAS Y DECORACIÓN DE LA CERÁMICA DEL ESTILO CAMPANARIO}

La muestra registrada ha sido agrupada por su forma detallándose en cada grupo el temperante, diámetro del gollete, tratamiento de la superficie externa, el espesor de las paredes y el tipo de gollete (Cuadro 1), también se ha detallado la técnica de elaboración, la cocción y la decoración exterior (Cuadro 2). Se registraron 9 formas de vasijas: ollas (Fig. 24), vasos (Fig. 25), tazones (Fig. 26), cántaros (Fig. 27), cuencos (Fig. 28), escudillas (Fig. 29), platos (Fig. 30), tinajas (Fig. 31) y ánforas (Fig. 32) y se han definido 4 tipos cerámicos: Campanario Inciso, Campanario Inciso con Aplicaciones, Campanario Moldeado y Campanario Pintado. Las asas (Fig. 33), figurinas (Fig. 34) y moldes (Fig .35) han sido agrupados como otras formas.

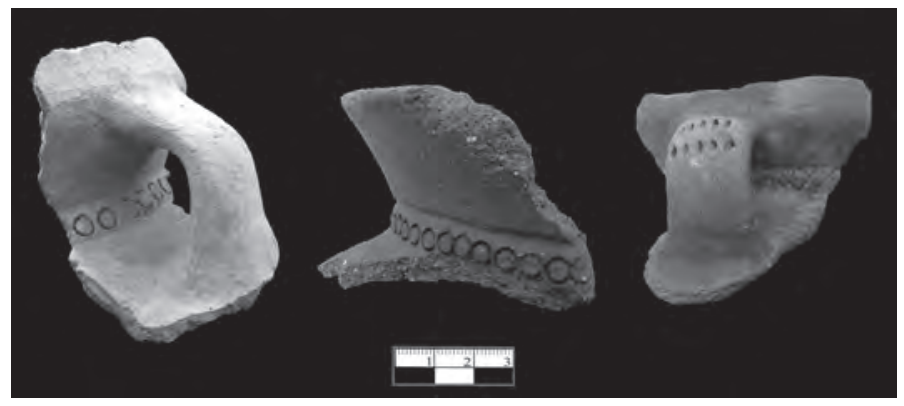

Figura 24. Ollas.

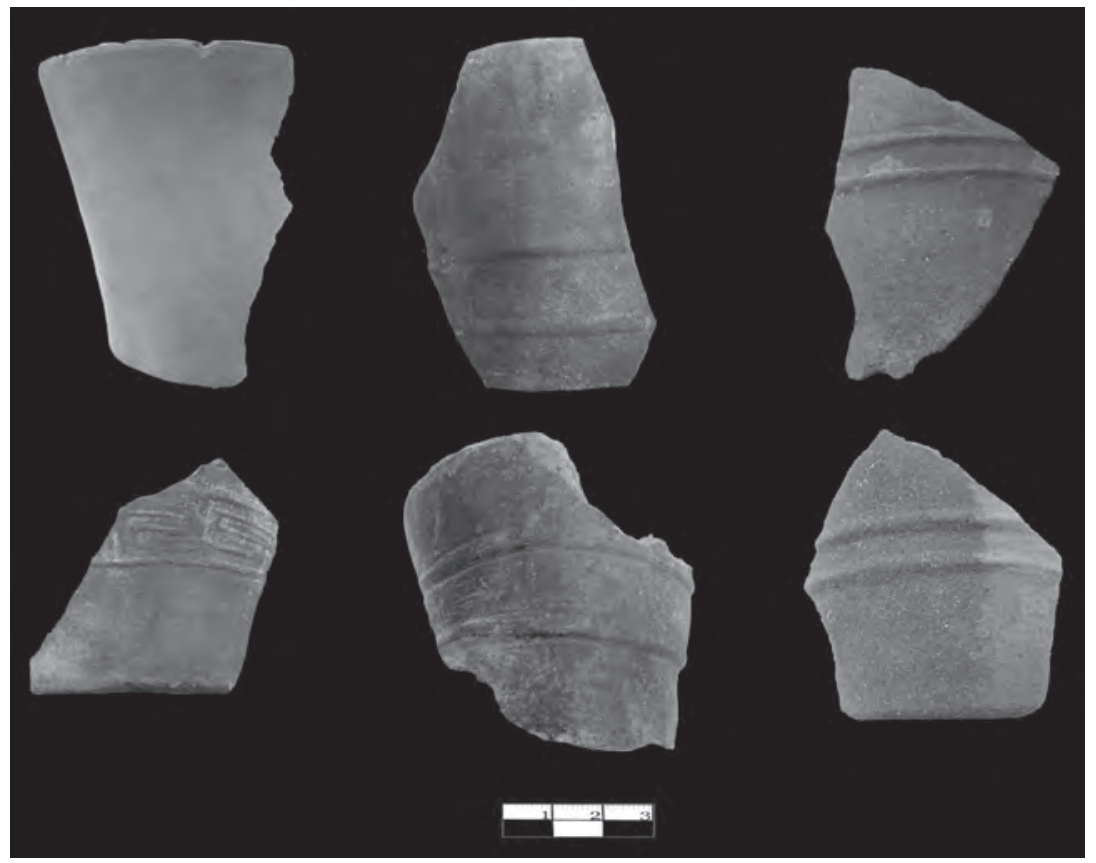

Figura 25. Vasos. 

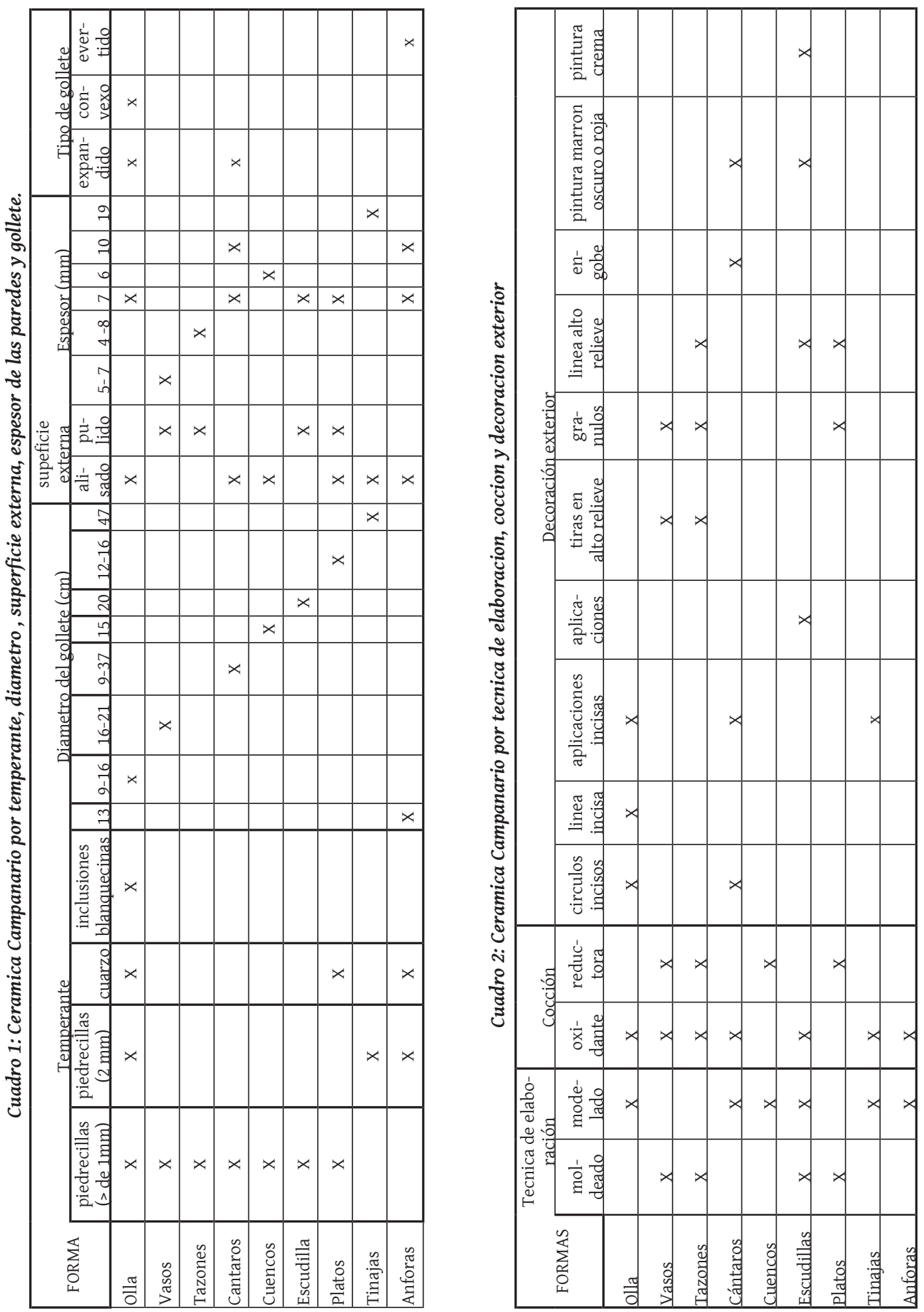


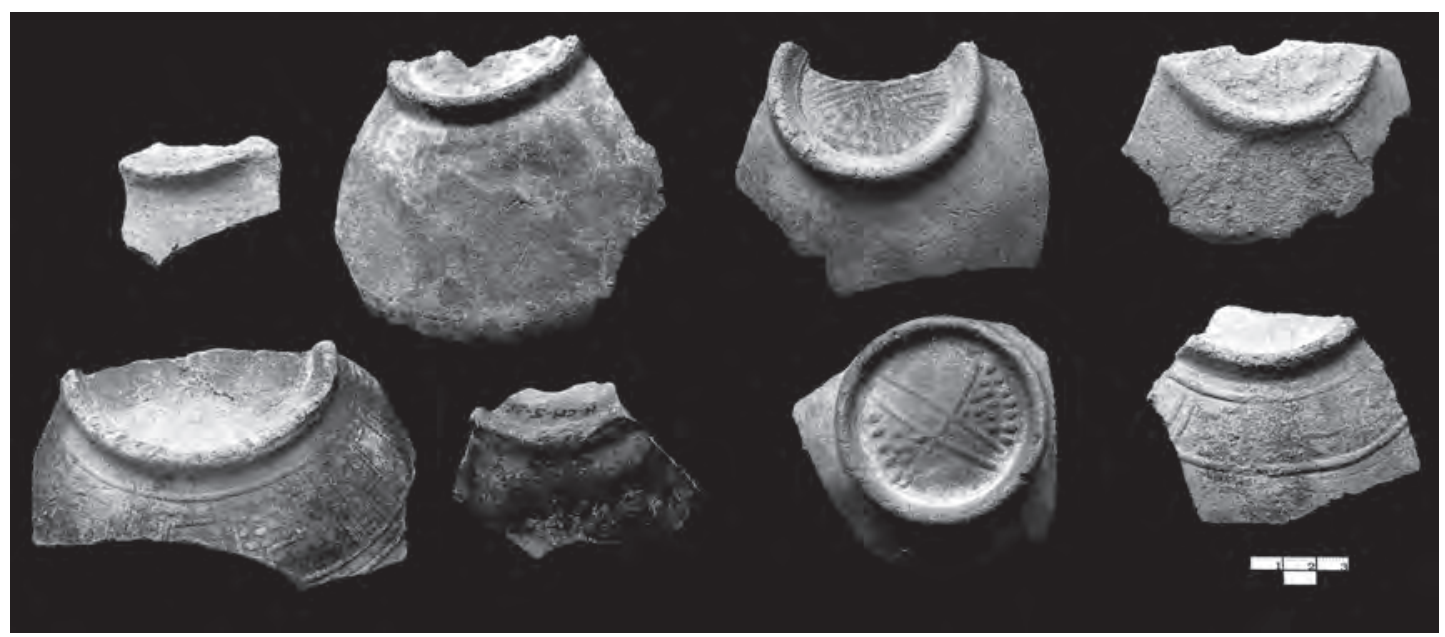

Figura 26. Tazones.

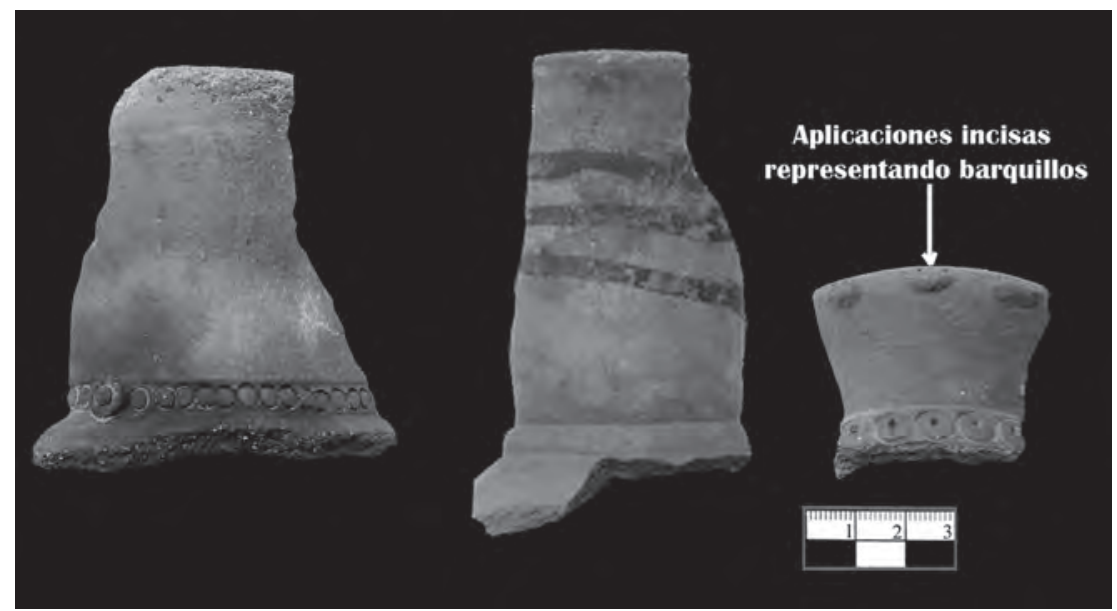

Figura 27. Cántaros.

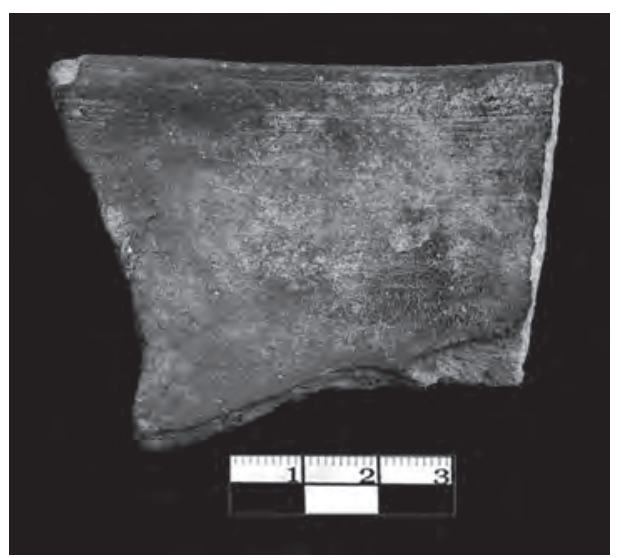

Figura 28. Cuencos.

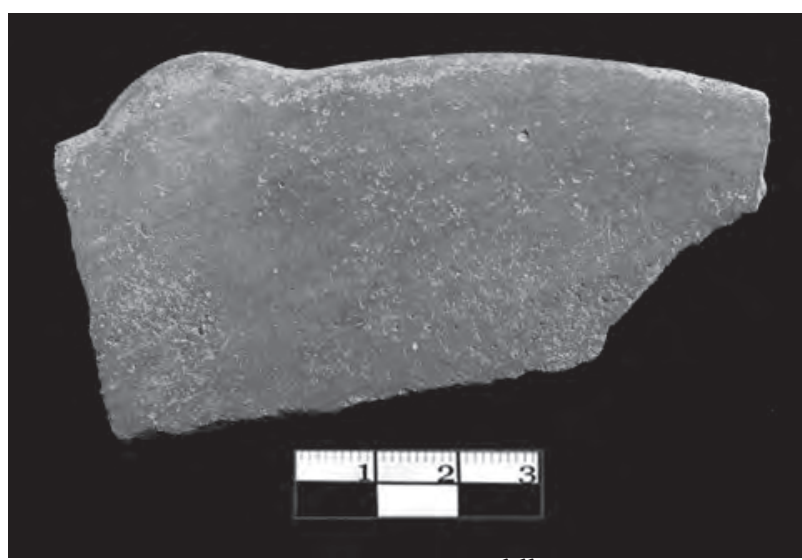

Figura 29. Escudilla. 


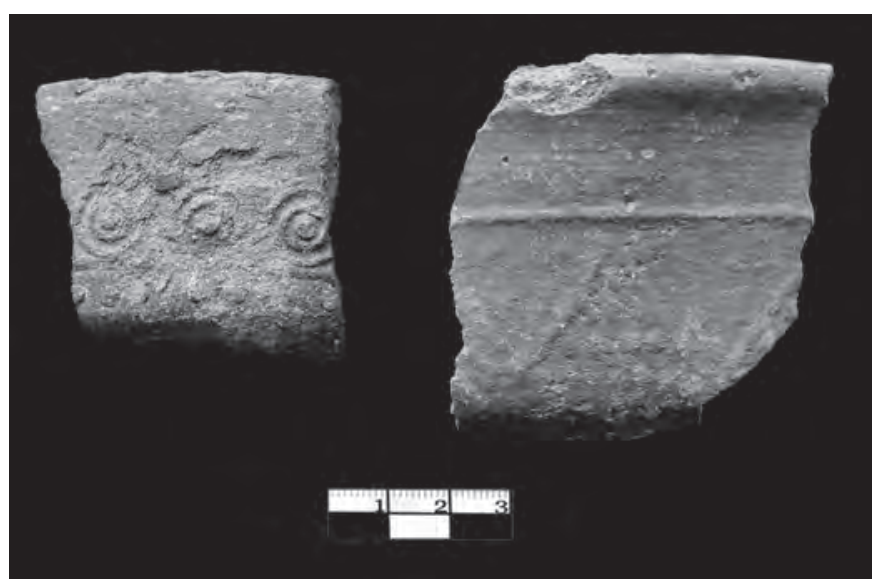

Figura 30. Platos.

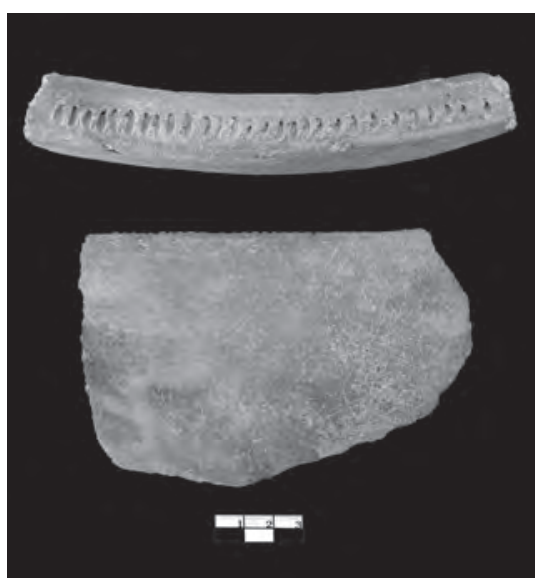

Figura 31. Tinaja.

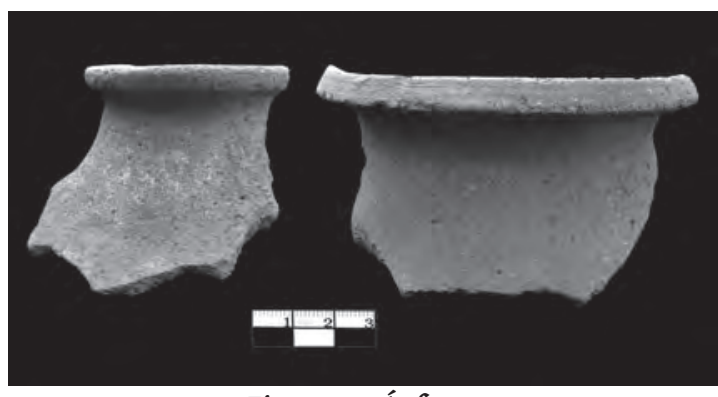

Figura 32. Ánforas.

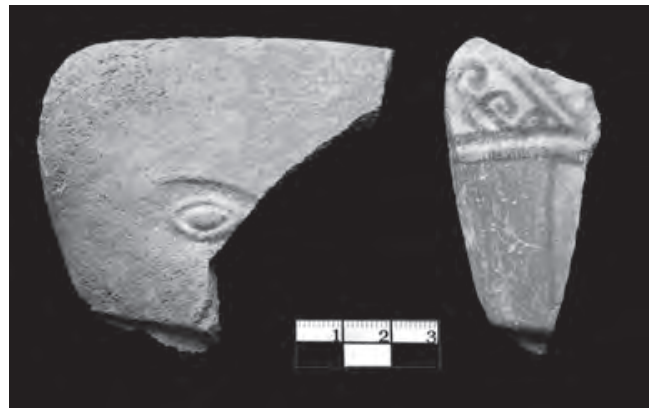

Figura 34. Figurinas.

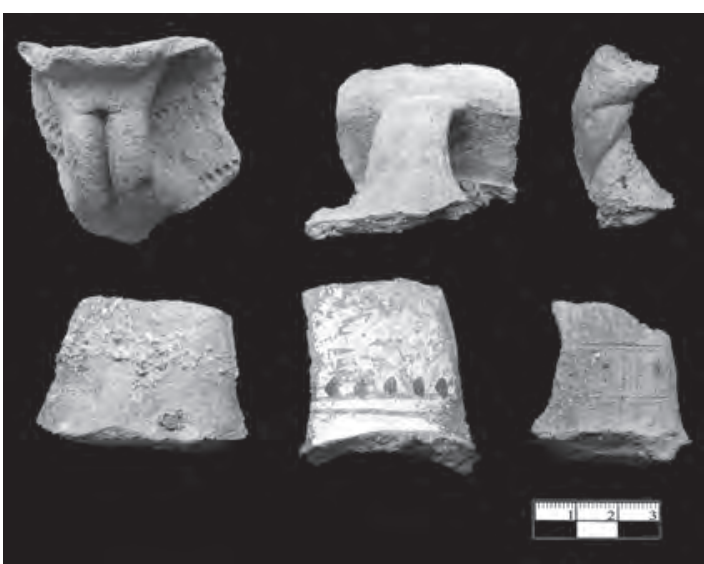

Figura 33. Asas.

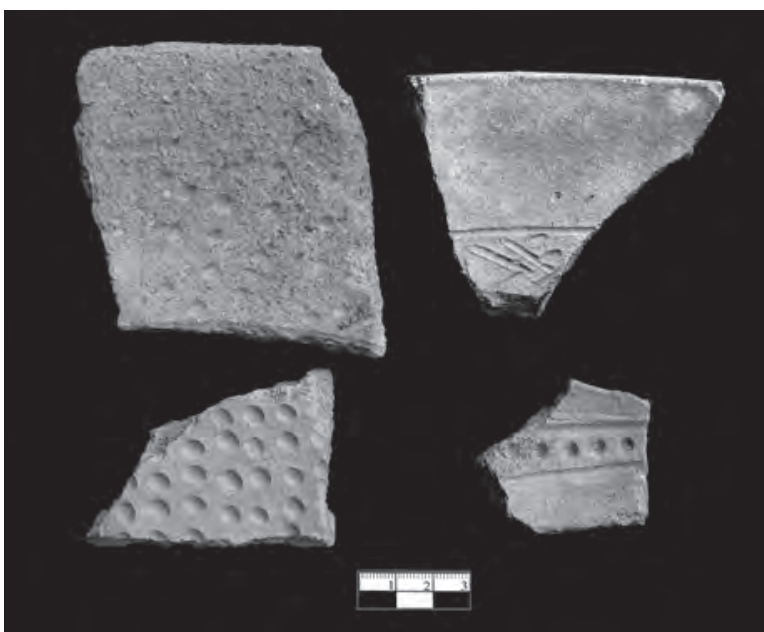

Figura 35. Moldes. 


\section{A. LAS TÉCNICAS DECORATIVAS}

\section{Campanario Inciso}

Consiste en decoraciones localizadas en los hombros de la vasija, se trata de líneas incisas paralelas que rodean toda la parte superior del cuerpo, en cuyo interior se han trazado líneas geométricas en forma de triángulos o escalonadas que simétricamente son decorados con puntos, alternándose con otros que se dejan sin decoración, logrando una simetría en toda la parte decorada (Fig. 36).

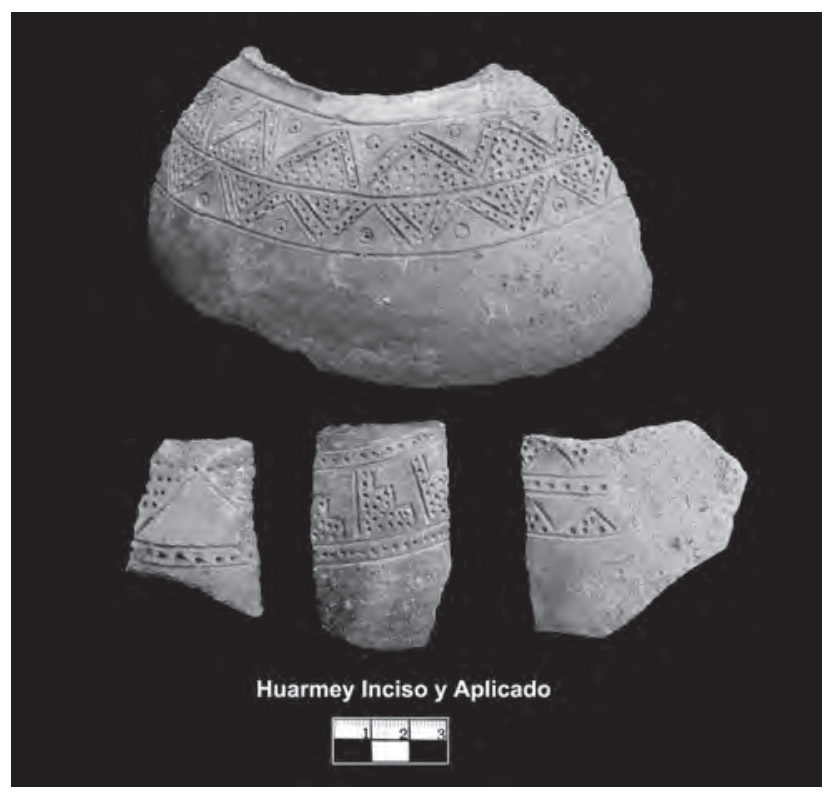

Figura 36. Huarmey Inciso.

\section{Campanario Inciso con aplicaciones}

La cerámica de Campanario también combina incisiones y aplicaciones, las vasijas presentan esta decoración desde la parte media y en su mayoría en la parte superior del cuerpo, en algunos casos incluye parte del mango o las asas, la distribución de la ornamentación se encuentra muy bien zonificada, con líneas incisas que remarcan los segmentos o la parte a decorar. La decoración consiste en incisiones circulares muy remarcadas o profundas generalmente con un punto central, combinando con un punteado que se alterna y zonifica en los hombros de las vasijas.

Los instrumentos empleados para lograr las incisiones posiblemente fueron carricillos, pequeñas varas de madera romas y afiladas. No sabemos si este arte se limitó a lo decorativo probablemente tendría algún valor histórico con mensajes subyacentes que ahora desconocemos, sin embargo el hallazgo de geoglifos (Fig. 23) cerca al pueblo de Huamba (Zavaleta et al. 2009: 42-45; Zapata 2012) con un diseño similar al círculo y punto y la cruz tan difundido en la decoración puede significar la continuación de su culto que se representó también en relieves de barro en Cerro Purgatorio (Vogel y Pacifico 2011: 379).

Este grupo de divide en:

a. Incisiones circulares (Fig. 37) hechas directamente sobre la arcilla en la unión del gollete con el cuerpo, mientras que sobre los hombros, de la misma vasija, se ha aplicado pequeños botones de arcilla que luego fueron presionados con un objeto circular y un punto central impregnándose la aplicación sobre la vasija; en otros casos estas vasijas también tienen dos aplicaciones modeladas (generalmente representaciones zoomorfas) en cada extremo de los hombros. En una misma vasija puede 


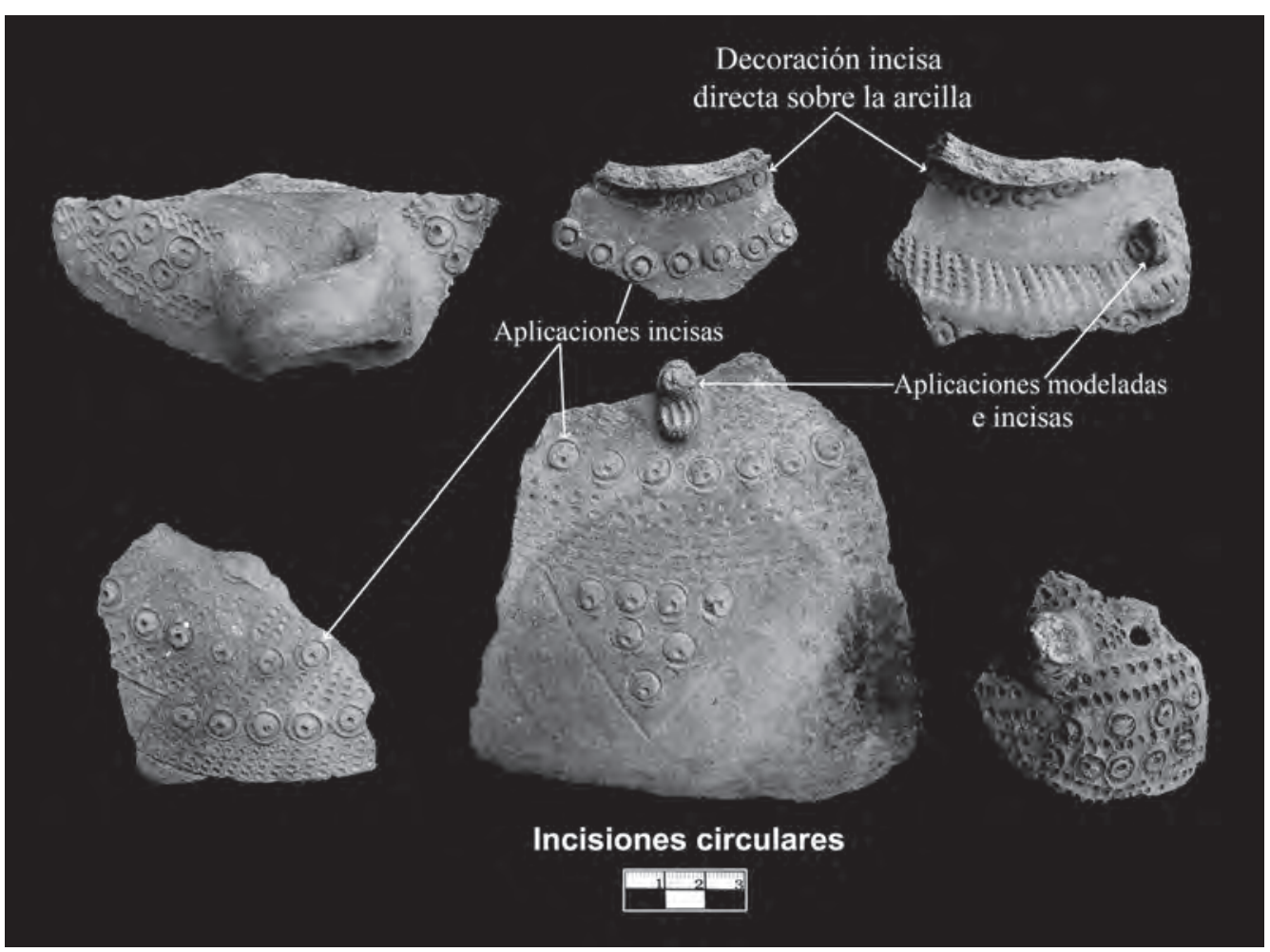

Figura 37. Cerámica incisa con aplicaciones.

haber una combinación de incisiones circulares hechas directamente sobre la arcilla en el chaflán de la base del cuello; aplicaciones sobre las que se realizó la incisión circular; puntos y rallas incisas distribuidos en bandas y leves aplicaciones delimitadas por un círculo inciso y con un punto en su parte central, muchas veces estas últimas aplicaciones parecen producto del moldeado pero son agregados modelados. Algunos cántaros presentan en su borde una serie de aplicaciones continuas con tres incisiones sobre cada una (Fig. 27), los pobladores locales afirman que se trata de la representación de las «lenguas» o barquillos (Enoplochiton niger, Acantopleura echinata).

Un grupo de vasijas fue decorado con aplicaciones modeladas (Fig. 38) (tiras, botones, rosetas, zoomorfas, etc) sobre las que se realizaron incisiones circulares o alargadas. Registramos un fragmento (Fig. 38d) de cerámica con aplicaciones que al mostrarle la fotografía, a los pescadores locales afirmaron que se trata de la representación de restos malacológicos conocidos localmente como «lenguas» o barquillos (Enoplochiton niger, Acantopleura echinata), del blanco, pausa o lapa (Fissurella sp.) y Scurria sp.

\section{Reconstrucción de las técnicas de aplicaciones e incisiones}

Hemos realizado la reconstrucción del proceso de aplicaciones sobre una base de arcilla, usando un carrizo de $5 \mathrm{~mm}$ de diámetro. Realizamos incisiones circulares directamente sobre la arcilla (Fig. 39a), similares a las presentes en las bases de los golletes, en una segunda hilera (Fig. 39b) hemos colocado aplicaciones que luego han sido presionadas con el carrizo delgado y se realizó la incisión con el punto central, estas dos últimas acciones permitieron impregnar permanentemente la aplicación sobre el cuerpo. También realizamos aplicaciones de una tira serpentiforme con incisiones circulares y junto a esta tres aplicaciones alargadas, de lo que representaría a las lenguas o barquillos, sobre las que realizamos incisiones (Fig. 39c) y una tercera aplicación (Fig. 39d) fue de grandes botones que luego al 


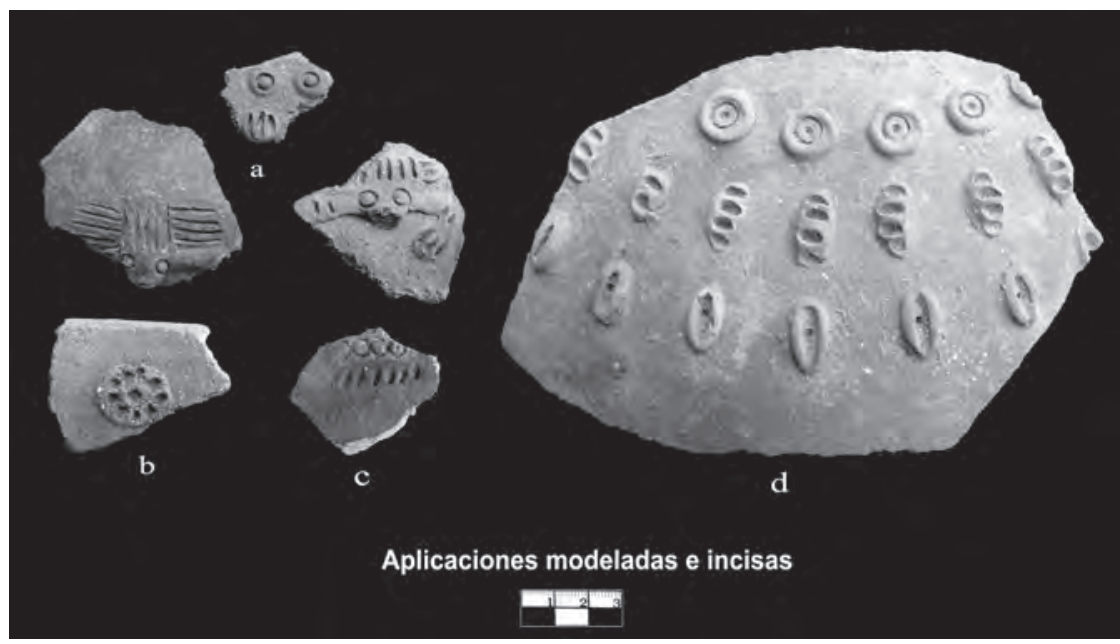

Figura 38. Cerámica incisa con aplicaciones.

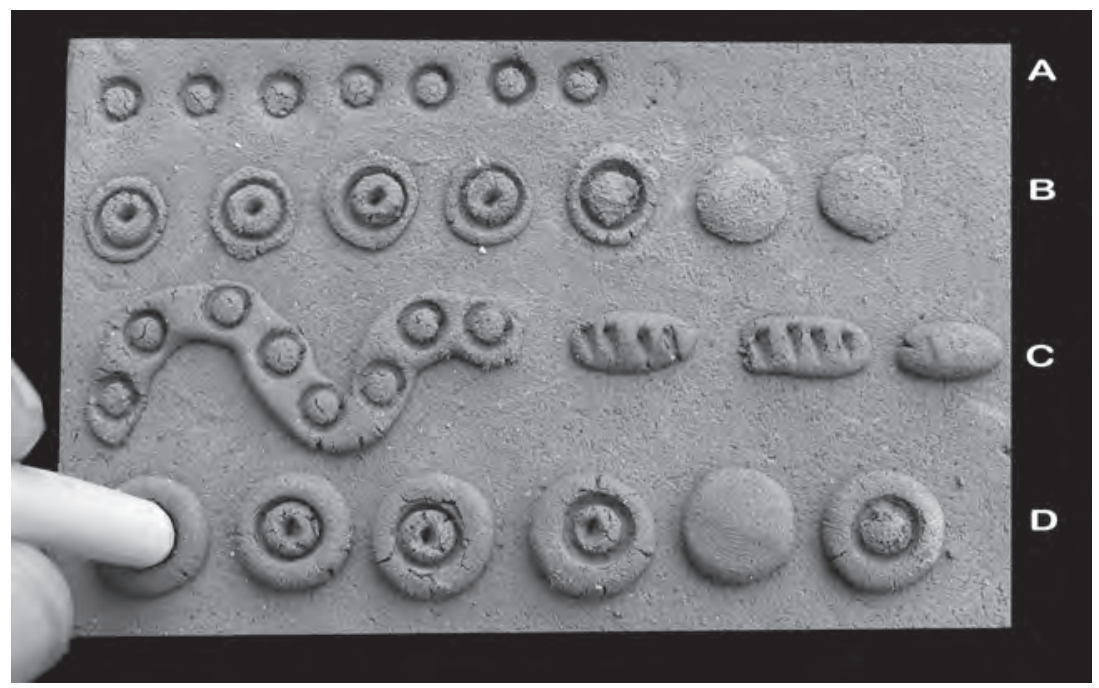

Figura 39. Reconstruccion de proceso de aplicaciones e incisiones.

presionarse con el carrizo se logró su unión al cuerpo. Esta técnica de decoración permitió, impregnar las aplicaciones de forma firme sobre el cuerpo de la vajilla.

\section{Campanario Moldeado}

La presencia de alto relieve que tienen la forma de grano de trigo o de piel de ganso, la estamos denominando gránulos, esta técnica decorativa es indicador del uso de moldes, que por la cantidad de fragmentos tuvo un uso intenso. Por los temas decorativos los dividimos en tres grupos:

- Un primer grupo (Fig. 40) diseños en alto relieve de «gránulos» dentro de bandas o segmentos definidos o delimitados por líneas en alto relieve, en algunos casos se alterna una banda de gránulos y otra se deja sin decorar.

- El segundo grupo (Fig. 41) son representaciones zoomorfas que resaltan la cabeza, mientras el cuerpo está definido por líneas en alto relieve y gránulos, también se registra algunas representaciones donde toda la decoración da apariencia de un plano relieve. 


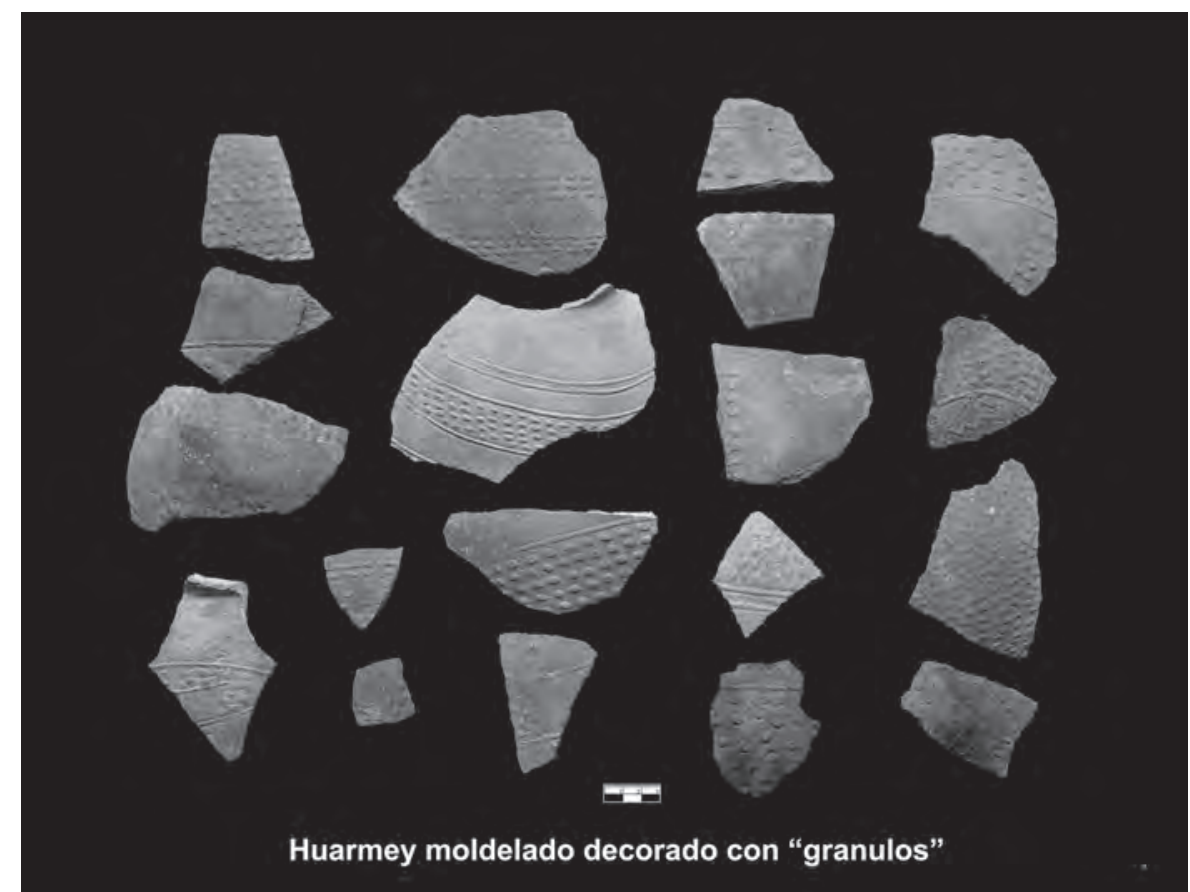

Figura 40. Ceramica moldeada, primer grupo.

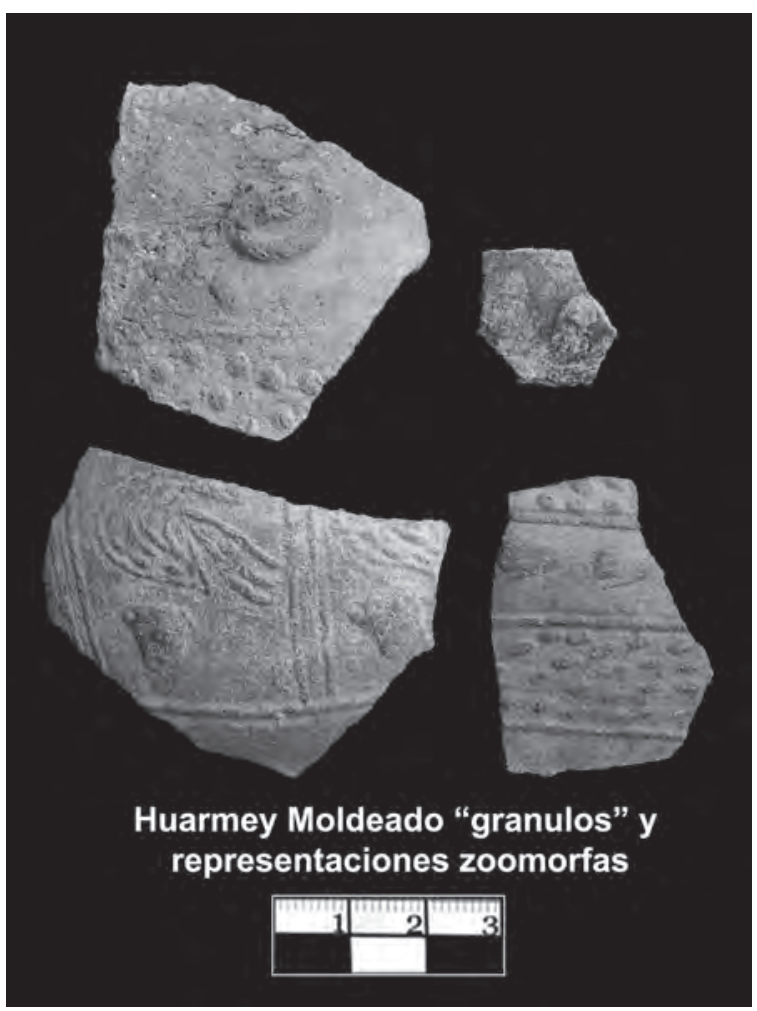

Figura 41. ceramica moldeada, segundo grupo. 
- El tercer grupo (Fig. 42) está conformado por gránulos que están colocados también dentro o alrededor de líneas escalonadas, rombos o rectángulos que son plasmados en alto relieve, muchas veces se alterna dejando los interiores sin decorar, creando una simetría bilateral.

- También hemos registrado aplicaciones moldeadas que tienen como característica haber sido confeccionadas a partir de moldes tomados de matrices reales (Fig. 43) por ejemplo tenemos un erizo de mar (equinoideo) y de una valva de «chanque» (Concholepas concholepas).

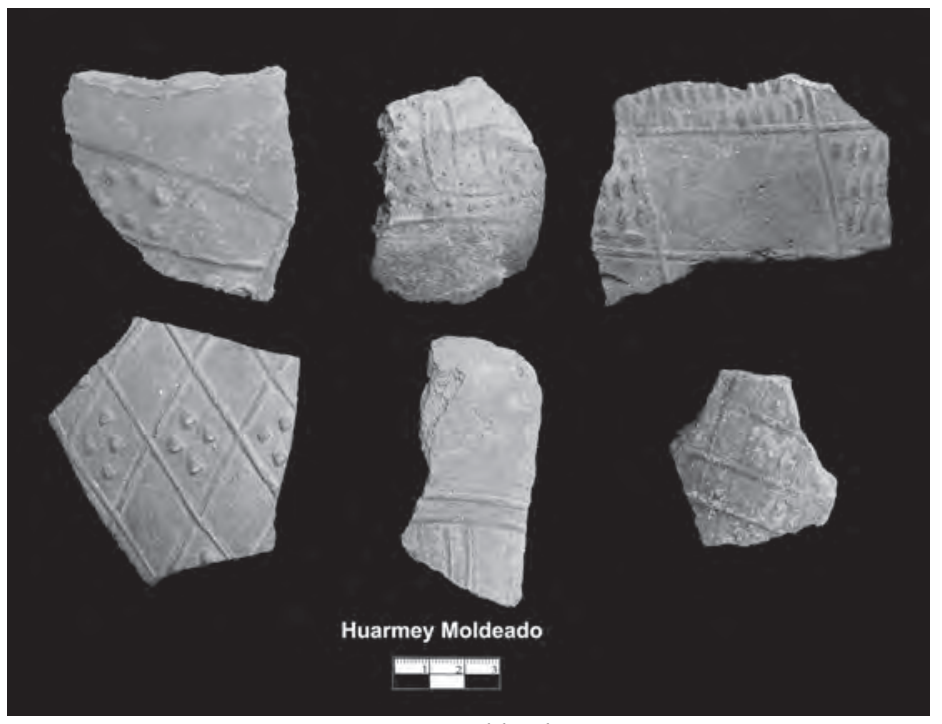

Figura 42. Ceramica moldeada. Tercer grupo.

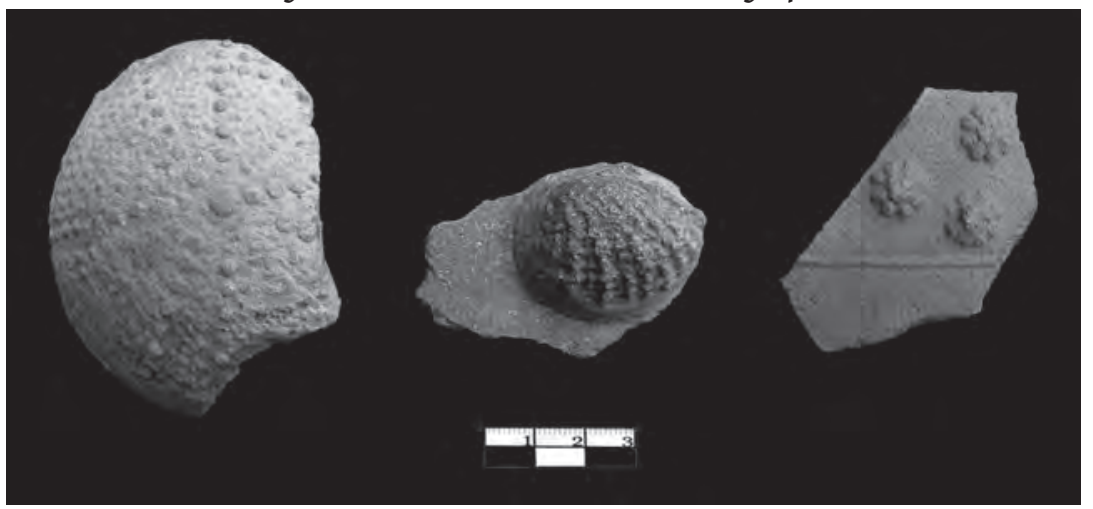

Figura 43. Ceramica moldeada.

\section{Campanario Pintado}

Fragmentos con pintura negra y crema.

En el Complejo Campanario existen escasos fragmentos que presentan pintura y que muestra reminiscencias del Horizonte Medio. Se ha registrado líneas geométricas gruesas crema y negro (Fig. 44), o crema (Fig. 45), que decora los bordes exteriores o interiores de las vasijas, en varios casos se observaron cuencos, platos o escudillas decorados; en un solo caso hemos registrado un cuenco pintado internamente de rojo y externamente de crema, todos estos fragmentos proceden del Cerro Campanario, Conjuntos 1 y 2. Según Vogel y Pacifico, que encuentra similar evidencia en Cerro Purgatorio, se trata del sub estilo «Rojo/Blanco/Negro» (2011: 366). 


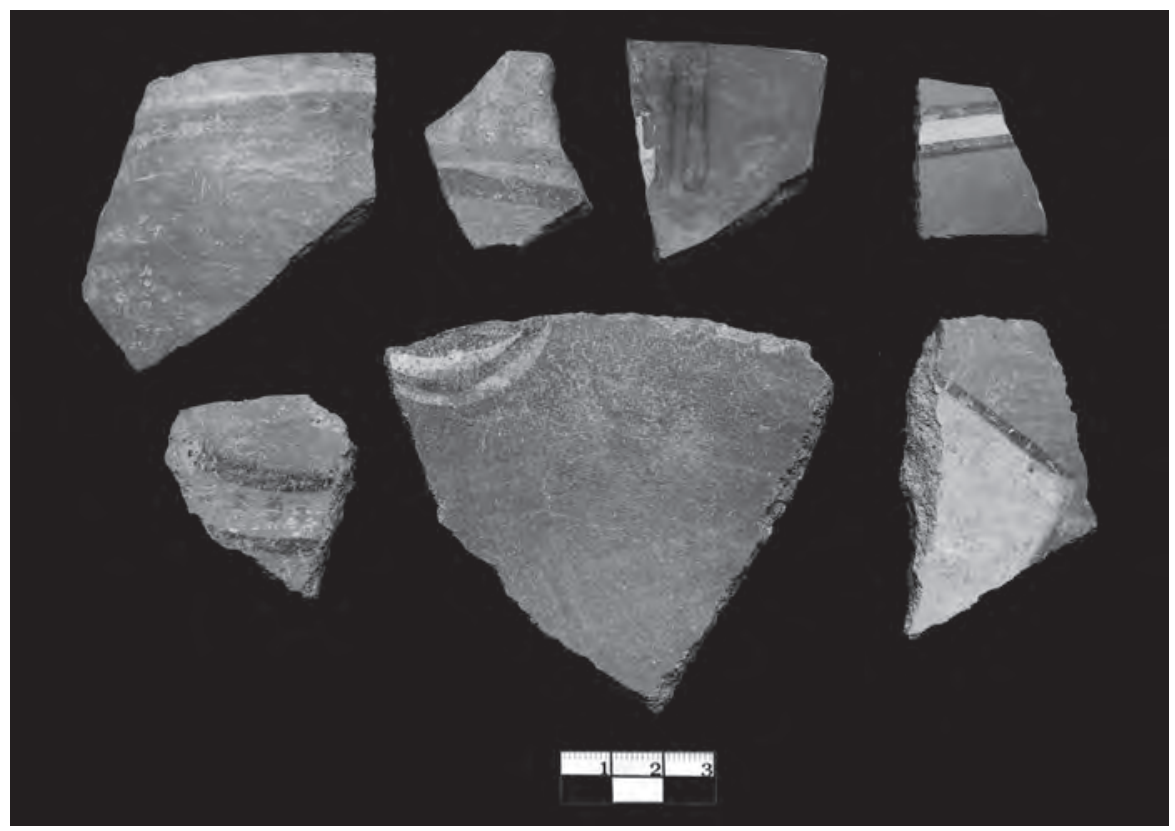

Figura 44. Fragmentos con pintura negra y crema.

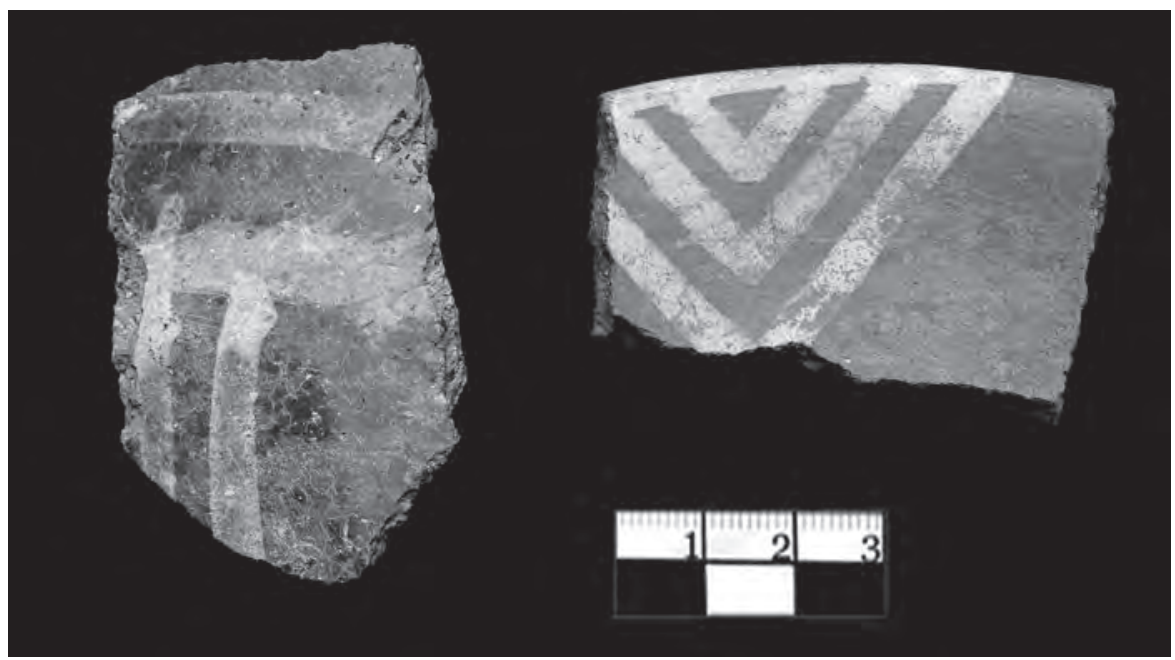

Figura 45. Fragmentos con pintura crema.

\section{OTRAS FORMAS}

\section{Asas}

Hemos registrado cuatro asas cintadas, un asa bifurcada y un asa trenzada (Fig. 33), han sido modeladas y quemadas en hornos abiertos. La decoración exterior presentó incisiones en base a líneas longitudinales y transversales, en otro caso se decoró con dos líneas marrones y seis puntos sobre fondo crema.

Un gollete con asa bifurcada muestra también la decoración de círculos incisos en la base del gollete además de círculos y puntos incisos en la parte superior del cuerpo. Un asa cintada tenía gollete convexo y decoración de círculos en la unión del cuerpo con el gollete y una aplicación. 
El asa trenzada recibió un tratamiento de un baño de engobe con una arcilla más oscura, esto puede observarse por la manera como se ha desprendido de su núcleo, quedando la arcilla base del asa, también se puede observar en un extremo las tres tiras de arcilla que al trenzarse conformaron el asa.

\section{Figurinas}

Se registraron dos fragmentos de figurinas moldeadas que presentan deformación craneana y un caso está decorado con líneas negras sobre crema. Su superficie es pulida.

\section{Moldes}

Hemos registrado cuatro fragmentos de moldes (Fig. 35), su elaboración y cocción indica un tratamiento especializado como una cocción completa y uniforme así como, el temperante de menor tamaño para permitir la absorción de humedad. Los temas decorativos en éstos, son gránulos y líneas. Uno de estos moldes esta decorados con gránulos en su pared exterior, dos moldes corresponden a vasijas abiertas, quizás tazones o cuencos.

La cerámica producida en Campanario muestra un manejo admirable de plasticidad de la arcilla, las canteras debieron localizarse en otras áreas porque en el valle bajo no se encuentra esta materia prima de buena calidad. El temperante corresponde a piedra granítica existente en el mismo sitio, muy fácil de dividirla en partículas; este mismo material, pero de mayor tamaño, se empleó en los adobes. En las vasijas con paredes más gruesas se ha encontrado evidencia de inclusiones vegetales que eran necesarios para obtener la plasticidad de la pasta. Para lograr una producción masiva los artesanos han recurrido al uso de moldes con modelos simples como vasos y ollas pero que luego del desmoldado seguía una segunda fase decorativa por medio de incisiones y aplicaciones. Estas dos últimas técnicas son los elementos que sustentan la maestría y especialización de los ceramistas. El tratamiento de la superficie en más del $99 \%$ es alisado, un vaso y un plato fueron pulidos el primero en la pared exterior, el segundo en el interior; la cocción predominante es oxidante, apenas 8 fragmentos se quemaron en horno cerrado.

\section{DISCUSIÓN, PROPUESTAS Y COMENTARIOS}

\section{DEFINICIÓN DE LA CERÁMICA CASMA}

Fue denominada Sechín por Kroeber (1944: 51), Casma por Tello (1956: 271), Casma Inciso por Collier (1962) y Koschmieder (2011: 406), Huarmey Inciso por Thompson (1966: 5) y «Casma Aplicado» o su equivalente el «Serpertino aplicado» (Daggett 1983). Desde sus inicios este estilo ha sido descrito, analizado y clasificado a partir de dos elementos exclusivamente ornamentales: la incisión (Collier 1962, Thompson 1964) y la aplicación que ha creado dos grupos de tratamientos decorativos: el Casma Inciso y el Casma Aplicado (Vogel y Vilcherrez 2007: 28).

Bastiand (2006) trabajó con una muestra de 58.123 fragmentos de cerámica procedentes de los sectores A, B y C en Cerro Sechín, estableciendo diez tipos cerámicos: Casma Impreso, Casma Aplicado, Casma Líneas Incisas, Casma Tira Aplicada, Casma Impreso Inciso-estampado, Casma Aplicado Impreso, Casma Aplicado Inciso, Casma Almendrado, Casma Impreso Inciso y Casma Pintado; a partir de estas propuestas se generalizó los análisis de los alfares Casma y que permiten tener una cronología relativa muy horizontal de fácil identificación. En uno de los trabajos más recientes, Vogel y Pacifico (2011: 366-367) identifican tres subestilos en Purgatorio: Casma Inciso, Casma Moldeado y un estilo Pintado con colores rojo/blanco y negro.

En el complejo Campanario tenemos cuatro tipos cerámicos: Campanario Inciso, Campanario inciso con aplicaciones, Campanario Moldeado y Campanario pintado. 


\section{CRONOLOGÍA DE LA CERÁMICA CASMA}

Hay un extenso y contradictorio margen cronológico asignado al estilo Casma. Fung y Williams (1977) propusieron una vigencia entre los 200 al 1470 d.C. contemporánea con Moche, Chimú e Inka, Proulx sostiene una duración mucho más estrecha, asociándola al Chimú Medio (1973: 60). Dagget (1983), en su análisis de cerámica Casma Inciso y Serpentino Aplicado procedente de Nepeña, lo asocia a los periodos Chimú Temprano y Medio respectivamente, además señala que «se halla en asociación con alfares rojizos moldeados a presión, y con un alfar pintado de rojo, blanco y negro. Para Wilson La cerámica NegroBlanco-Rojo sería procedente de la primera mitad del Horizonte Medio, cuando Moche perdió su dominio hacia el sur, el poder político de este estilo sería el sitio el Purgatorio (Wilson 1988: 334-335).

Otro dato de contextualización cronológica de la cerámica Casma es reportado por Pimentel y Paredes, quienes hacen un registro de caminos en el valle de Chao y mencionan «Un hecho que llama nuestra atención es el hallazgo frecuente de cerámica comparable al denominado Chimú Temprano[...] así como cerámica de estilo Casma en asociación con cerámica Moche V. Cerámica de estos tres estilos del Horizonte Medio se encuentra tanto en la superficie como en las unidades excavadas. Por otro lado, la estratigrafía de las unidades excavadas refleja una sola ocupación. (Pimentel y Paredes 2003: 298). EL dato de un registro estratigráfico asociado a cerámica Casma los reporta Bastiand, quien analiza un entierro con tres vasijas: una olla del estilo Casma (tipo Casma Impreso Inciso-estampado de borde decorado) y dos cántaros, uno CasmaChimú (Casma: tipo Aplicado Inciso y Chimú: morfología), de color naranja y el otro como Chimú-Inka de color negro, esta evidencia le sirve para proponer que la llegada de la influencia Chimú, «...del que recibe el mayor impacto, no implicó la destrucción total del asentamiento local. La supervivencia del estilo Casma hasta el final de las últimas ocupaciones en el Sitio (Inca) lo demuestra (Bastiand 2006: 110).

En recientes investigaciones en el valle de Culebras se propone una escala cronológica comprobada por relaciones estratigráficas (Giersz 2009: 4) donde se establece 10 fases. En el Periodo Molino (700-850 d.C.) «[...] aparece una nueva tradición de cerámica local, que tiene una amplia distribución territorial. Esta cerámica, de cocción oxidante, decorada en el estilo Casma Impreso de molde[...]» la iconografía está relacionada con arcaísmos Moche y personajes con báculos de la iconografía Tiahuanaco y Wari. Otro componente local de este periodo es la cerámica con decoración pintada blanco, anaranjado y negro sobre rojo, con diseños geométricos y una nueva forma de vaso ceremonial kero, junto a cerámica foránea como la de los estilos Wari de Viñaque y Pachacamac (Giersz 2009: 11). El periodo Ten Ten (1000-1450 d.c.) representa al surgimiento de una nueva entidad política, el valle de culebras llega a su máxima complejidad socioeconómica. Ten Ten es el sitio de mayor dimensión y complejidad con arquitectura administrativa y residencial, plazas públicas y pirámides con rampa. En esta fase se registra el estilo Casma Inciso con diseños geométricos mayormente círculos, puntos y aplicaciones zoomorfas que continuan hasta la presencia Inka.

Koschmieder (2011) registra que en el valle de Casma el estilo Formativo Tardío Patazca es reemplazado en el Intermedio Temprano por el estilo Casma modelado que es hallado junto a vasijas moche. Las representaciones se caracterizan por ser animales con rasgos antropomorfos y de personajes con tocados elaborados que parecen imitar a los temas moche. En la fase final del Horizonte Medio aparecen los temas de personajes con báculos y atributos del maíz; a fines de este Horizonte aparece el estilo Casma Inciso que continua hasta la época Colonial Temprana.

Las recientes evidencias del valle de Culebras confirman que el estilo Casma Inciso y Aplicado corresponde a un momento posterior e inmediato al estilo impreso y el tricolor del Horizonte Medio que se asocia a la influencia Wari en la costa central desde donde se irradia a toda la costa norte.

En Campanario al no haberse realizado excavaciones, ni mediciones, aún no esta determinada su cronología, probablemente una expansión iniciada en Cerro Purgatorio influenció en los valles de Culebras y Huarmey, alrededor del año 1000 d.C., para el sitio de Campanario es un dato interesante que no se ha observado cerámica Chimú o tampoco evidencia de cerámica Chimú bajo influencia Inka, que tiene fuerte presencia en el valle. El conocimiento actual en Huarmey nos indica que los Campanario arriban alrededor del 1000 d.C. y se mantienen hasta 1470 cuando los Inkas llegan al valle. 


\section{EL HORIZONTE MEDIO EN HUARMEY}

La presencia de vasos, vasijas pintadas en negro y crema y otras formas que no corresponden al estilo Casma, en Campanario, serían los rezagos del grupo cultural del Horizonte Medio que habría tenido como sitio principal El Castillo de Huarmey (Makowski et al. 2011: 255-258), para esa época los valles de Huarmey y Casma influenciados por el dominio Moche quedaron independientes por estar ubicados en el extremo más alejado de la capital y con la crisis acaecida en el valle de Moche (Uceda 2008: 280; Thompson 1964: 18), esta libertad de los compromisos, alianzas , acuerdos o tratos permitió aceptar y recibir influencia del Horizonte Medio desde Pachacamac (Kroeber 1926: 30; Menzel 1968: 193, 1977: 48) y desde el Callejón de Huaylas (Menzel 1968: 186; Paredes y otros 2000: 287). La presencia de rutas de transporte transversal (como la quebrada Carcar y Gallinazo) y longitudinal (paralelo al Río rio Huarmey y varias rutas entre las quebradas) facilitaron la difusión del nuevo estilo entre Supe, Huarmey y Casma con dos estilos, uno denominado «impreso» que corresponde a vasijas moldeadas y otro a cerámica pintada y moldeada decorada con pintura rojo, blanco y negro.

En Huarmey el sitio principal de esta cerámica impresa y pintada se localizó en El Castillo, donde se puede hallar tres áreas bien definidas: la plataforma, el área residencial con muros de tapia y el cementerio saqueado que presenta gran cantidad de fragmentos de esta cerámica mencionada. Otros dos cementerios hemos registrado en el sector El Lecheral, se trata de un sitio con cerámica similar a la que se ha registrado en El Castillo de Huarmey. Un tercer sitio con fuerte presencia impresa y tricolor está localizado sobre una plataforma formativa localizada la quebrada Mandinga, se enterraron los cuerpos en fosas simples rompiendo la arquitectura, el intenso saqueo ha dejado varios fragmentos en la superficie.

Retomando la presencia de este nuevo estilo entre los valles de Supe, Huarmey y Casma, proponemos que su independencia política permitió que adopten nuevos estilos, los adapten a su propia producción y difundan hacia la costa norte; su duración correspondería desde los años 700 al 1000 d.C. (Gierzs 2009). No hay evidencia que señale la presencia estatal, impositiva y tributaria de los Wari en Huarmey, solamente la iconografía de origen Wari que se difunde a lo largo de la costa y sierra de Ancash y que en Huarmey está focalizada en sitios específicos y no en todo el valle, a diferencia de la cerámica Campanario Incisa, Aplicada y Moldeada, que está presente desde el 1000 d.C. hasta la época Colonial temprana (Koschmieder 2011) y se encuentra distribuida en todo el valle de Huarmey. La cerámica Campanario se trata del estilo venido del sitio Purgatorio en Casma, una comparación ornamental entre los fragmentos Casma Inciso hallados en Cerro la Cruz, Purgatorio, Culebras y Huarmey no muestra diferencias; sin embargo, la decoración que hemos denominado gránulos parece ser una variante local u otra tradición.

\section{Los ESTILOS CONTEMPORÁNEOS A LA CERÁMICA CAMPANARIO}

En el complejo Campanario de Huarmey encontramos que el grupo que hemos clasificado como Campanario Moldeado corresponde a la tradición Tanguche en el valle de Santa particularmente en su técnica estampada, que emplea temas decorativos como «piel de ganso», diseños geométricos, animales, plantas y elementos de la naturaleza como olas; también comparte las aplicaciones que pueden ser en forma de serpientes incisas (Belisle 2008: 25). En Santa la cronología del Tanguche se divide en Temprano (650 d.C.) y Tardío (1150 d.C.). En Campanario de Huarmey, la producción moldeada es contemporánea con la característica cerámica Casma incisa y aplicada, que correspondería al Tanguche Tardío, donde son contemporáneos los estilos cerámicos Casma y Estampado (Wilson 1988: 9). En el valle de Huarmey la cerámica Tricolor está asociada al sitio El Castillo cuyo estampado, en las ollas, característico es similar al estilo San Nicolás y San Juan Moldeado del valle de Virú (Ford y Willey 1949). En Huarmey, 1 as dos tradiciones el Casma Inciso y Aplicado con el Moldeado comparten un mismo espacio y una misma época que coincidiría con los fechados absolutos para el Tanguche Tardío (900-1150 d.C.) que correspondería a la decadencia del Estado Negro-Blanco-Rojo (Belisle 2008:26). Si 
El Castillo de Huarmey fue el sitio principal del Horizonte Medio desde donde se sustentó el estado «Tricolor», este sería el antecesor del Campanario donde luego de la época de «Libertad y desorden sociopolítico» desde Cerro Purgatorio se implanta un gobierno estatal alrededor del 1000 d.C. dejando reminiscencias de los estilos anteriores pero imponiendo el inciso y aplicado.

\section{LA ORGANIZACIÓN DEL GOBIERNO MULTIVALLES Y LA CERÁMICA CASMA INCISO - APLICADO}

Una de las características de la cerámica Casma es su homogeneidad intervalles en su decoración, esta es un indicador de una sola tradición y gobierno político, aun no estamos en el nivel de conocimiento para identificar los aportes o diferencias en cada valle, al parecer la decoración con gránulos en Campanario correspondería al estilo Tanguche. La homogeneidad estilística de la cerámica Casma Incisa y Aplicada en el territorio desde el valle de Huarmey hasta el valle de Chao nos conduce hacia una interrogante que aún espera respuesta ¿a pesar de la distancia, que separa cada valle con cerámica Casma, se mantuvo un poder central en cerro Purgatorio o cada capital de provincia gobernó de manera independiente sus recursos?.

En Campanario, que gobernó todo el valle, necesitó de un gran número de servidores del estado que básicamente administraban el valle en todos sus aspectos productivos y del control de las vías de comunicación. La presencia de una extensa área con arquitectura en cerro Purgatorio con plazas, patios y depósitos fue «la Capital» desde donde se planificaba las acciones de sus centros administrativos secundarios y se recababa los bienes de uso y consumo que serian trasladados hacia Purgatorio.

Aún no es posible conocer cómo arribó y que sucedió luego del establecimiento y dominio de este grupo con cerámica Casma que domina todo Huarmey e incluso tiene sus propios mallquis que rinden culto, todo parece indicar que en este tiempo, existió autonomía política en este valle y quizás se llegó a un gobierno que se independizó y esto parecería ser el mismo caso del valle de Culebras, si esto sucedió, en Casma el sitio Purgatorio debió debilitarse y perder varios de sus territorios sujetos a su administración.

\section{CONCLUSIONES}

1. Alrededor del año 1000 d.C. sucede el fin del Horizonte Medio y decae el sitio El Castillo y se instala un nuevo grupo cultural que residió y gobernó desde el Complejo Campanario donde se diseñan cinco sectores con actividades especificas: una plataforma cercada por tres muros concéntricos, arquitectura administrativa y residencial, en Cerro Campanario; el sector con arquitectura urbana, los depósitos y los cementerios. Así mismo, se instaló sitios administrativos secundarios en diversos lugares para controlar las actividades productivas y la movilización de bienes.

2. Cuatro fueron los principales recursos que soportaron la economía y poder de los gobernantes: la obtención de recursos alimenticios del mar, las rutas para el trasporte horizontal y vertical, Canteras de minerales y la presencia del cerro Toledo donde se desarrollaron intensas actividades rituales.

3. La cerámica presenta cuatro tipos: Campanario Inciso, Campanario Inciso con Aplicaciones, Campanario Moldeado y Campanario Pintado, por su forma registramos: ollas, vasos, tazones, cántaros, cuencos, escudillas, platos, tinajas y ánforas y para otras formas tenemos asas, figurinas y moldes. El tipo moldeado presenta características técnicas y ornamentales similares al Tanguche Tardío.

4. La homogeneidad estilística y decorativa de la cerámica Casma nos indicaría una presencia estatal; sin embargo, se debe ampliar y profundizar las investigaciones para poder responder que venciendo las distancias que separa cada valle con cerámica Casma, se mantuvo un poder central en cerro Purgatorio o cada valle manejó de manera independiente sus recursos. 


\section{Agradecimientos}

Agradecemos a los pobladores de Huarmey, un pueblo excelso, que nos ha permitido conocer su territorio, su pasado y reconocer que es un paraíso de riqueza esperando por una oportunidad para lograr su desarrollo, que tanto le está costando, y que ve en el turismo una de las opciones para alcanzar su autosostenimiento.

\section{BibliografíA}

ARRIAGA, Pablo José de

1968 [1621] Extirpación ce la Idolatría en el Perú. Crónicas peruanas de interés indígena.BAE. Madrid

BASTIAND, María

2006 «El estilo de la cerámica Casma del Intermedio Tardío». Investigaciones Sociales. 17 (X): 91-119. Lima.

BELISLE, Veronique

2008 «El Horizonte Medio en el Valle del Santa: continuidad y discontinuidad con los mochicas del Intermedio Temprano». En: J. Castillo, H. Bernier, G. Lockard y J. Rucabado (eds.). Arqueología Mochica: Nuevos enfoques, Actas del Primer Congreso Internacional de Jóvenes Investigadores de la Cultura Mochica (Lima, 4 y 5 de agosto de 2004): 17-31. Lima: PUCP - IFEA.

BONAVIA, Duccio

1982 Los Gavilanes. Lima: Corporación Financiera de Desarrollo.

BONAVIA, Duccio; L, JOHNSON-KELLY; E, REITZ y E. WING

2001 «El Precerámico Medio de Huarmey: Historia de un Sitio (PV35-| 106)». Bulletin de l'Institut Français d' Etudes Andines 30 (2): 265-333. Lima

COLLIER, Donald

1962 «Archaeological investigations in the Casma Valley, Peru». En: Akten des 34 international en Amerikanisten kongress, Wien, 1960, pp. 411-417. Viena: Verlag Ferdinanad Berger, Horn.

CURATOLA, Marco y Mariusz ZIÒLKOWSKI

2011 Adivinación y Oráculos en el Mundo Andino Antiguo. Lima: PUCP - IFEA.

DAGGET, Cheryl

1983 «Casma Incised Pottery: an Analysis of Collections from the Casma Valley». En: D. Sandweiss (ed.) Investigations of the Andean Past: 209-225. Cornell University Latina American Studies Program, Ithaca, New York.

DONNAN, Christopher y Carol MACKEY

1978 Ancient Burial Patterns of the Moche Valley, Peru.Austin: University of Texas Press.

DÍAZ REYES, Miguel

2008 «Los Marisqueros de Huarmey». Revista de la Municipalidad Provincial de Huarmey 1: 40-43. Huarmey.

FALCON HUAYTA, Víctor y Rosa MARTINEZ NAVARRO

2008 «Un tambor de cuero pintado del Museo nacional de Arqueología. Antropología e Historia del Perú». Anales del Museo de América 16: 9-28. Universidad de La Rioja. España

FORD, james y Gordon WILLEY

1949 «Surface Survey of the Virú Valley, Perú». Anthropological Papers of the American Museum or Natural History, 43(1). New York.

FUNG, R. and WILLIAMS LEÓN, C.

1977 «Exploraciones y Excavaciones en el Valle de Sechín, Casma». Revista del Museo Nacional XLIII. Lima.

GIERSZ, Milosz

2009 «Cronología Cultural y Patrones de Asentamiento Prehispánico en el Valle del Rio Culebras, Costa Norcentral del Perú». ARKEOS, revista electrónica de la arqueología Pontificia Universidad Católica.Vol. 4 (11): 1-40. Lima. 
2011 «Los Guardianes de la Frontera Sur: la presencia Moche en Casma y Culebras». En: M. Giersz e I. Ghezzi (eds.) Arqueología de la Costa de Ancash. Travaux de l'Institute Français d' Etudes Andines. 290: 271-230. ANDES, Boletín del Centro de estudios Precolombinos de la Universidad de Varsovia. 8. IFEA. Varsovia - Lima.

GIL GARCÍA, Francisco

2002 «Donde los Muertos no Mueren. Culto a los antepasados y reproducción social en el mundo andino. Una discusión orientada a los manejos del tiempo y el espacio». Anales del Museo de América. 59-83. Madrid.

INSTITUTO NACIONAL DE CULTURA - REGIONAL DE ANCASH

2007 Propuesta de Delimitación del Complejo Campanario. Presentado al INC - Lima.

INSTITUTO NACIONAL DE ESTADISTICA E INFORMATICA (INEI)

1994 III Censo Agropecuario. Perú.

KOSCHMIEDER, Klaus

2011 «Estrategias de subsistencia en la periferia sur del imperio Chimú: el caso de Puerto Pobre, Valle de Casma». En: En: M. Giersz e I. Ghezzi (eds.) Arqueología de la Costa de Ancash. Travaux de l'Institute Français d' Etudes Andines 290: 399-448. ANDES, Boletín del Centro de estudios Precolombinos de la Universidad de Varsovia. 8. IFEA. Varsovia - Lima.

KROEBER, Alfred

1926 «Archaeologycal Explorations in Peru, Part I: Ancient Pottery from Trujillo». Anthropology Memoirs, Field Museum of Natural History 2 (1). Chicago.

1944 «Peruvian Archaeology in 1942». Viking Fund Publicatons in Antropology, 4.New York, wenner-greenm Foundation.

LARCO HOYLE, Rafael

1938 Los Mochicas. Tomo I. Lima: Casa editora la Crónica y Variedades S.A

MACKEY, Carol J.

1986 «La Cerámica Chimú a Fines del Horizonte Medio». Revista del Museo Nacional 47: 73-91. Lima, Perú 1983-1985.

MAKOWSKi, Krzysztof; Milosz GIERSZ y Patryca PRZADKA

2011 «La Guerra y la Paz en el Valle de Culebras: Hacia una arqueología de Fronteras». En: En: M. Giersz e I. Ghezzi (eds.) Arqueología de la Costa de Ancash. Travaux de l'Institute Français d' Etudes Andines. 290: 231-270. ANDES, Boletín del Centro de estudios Precolombinos de la Universidad de Varsovia

8. IFEA. Varsovia - Lima.

MENZEL, Dorothy

1968 La Cultura Wari. Lima: Compañía de seguros y reaseguros Peruano-Suiza S.A.

OLIVIER Le Guen

2008 «UBÈEL PIXAN: el camino de las almas. Ancestros familiares y colectivos entre los Mayas Yucatecos». Península 3 (1): 83-120. Yucatán: Centro Peninsular en Humanidades y Ciencias Sociales, Universidad Nacional Autónoma de México.

PAREDES, Juan; Berenice QUINTANILLA y Moisés LINARES

2000 «Tumbas de la Época Wari en el Callejon de Huaylas, Ancash». En: P. Kaulicke y W, Isbell (eds.) Huari y Tiwanaku: modelos vs. Evidencias. Boletín de Arqueología PUCP 4: 253-288. Primera parte. Lima: PUCP.

PIMENTEL, Víctor y María Isabel PAREDES

2003 «Evidencias Moche V en tambos y Caminos entre los Valles de Santa y Chao, Perú». En: S. Uceda y E. Mujica (eds). Moche: hacia el final del milenio. Actas del segundo Coloquio sobre la cultura Moche (Trujillo, 1 al 7 de agosto de 1999), Tomo I: 269-303. Universidad Nacional de Trujillo y PUCP.

POZORSKI, Thomas y Shelia POZORSKI

1996 «Cerámica de la cultura Moche en el valle de Casma, Perú». Revista del Museo de Arqueología, Antropología e Historia 6: 103-122. Trujillo, Facultad de Ciencias Sociales, Universidad Nacional de Trujillo. 
PROULX, Donald A.

1973 Archaeological Investigations in the Nepeña Valley, Peru. Department of Anthropology, Research Report 13. University of Massachussets. Amherst.

PRÜMERS, $\mathrm{H}$.

2000 «El Castillo de Huarmey una Plataforma Funeraria del Horizonte Medio». Boletín de Arqueología PUCP (4): 289-312. Lima.

REYNA ZEGARRA, Ernesto

2013 Los Tesoros de Huarmey. A.F.A. Editores Importadores S.A. Segunda Edición. Perú.

SHIMADA, Izumi

1994 Pampa Grande and the Mochica Culture. Austin: University of Texas Press.

TELLO, Julio C.

1956 Arqueología del valle de Casma. Informes de los trabajos de la expedición arqueológica del Marañón 1937. Publicación antropológica del archivo J.C. Tello de la UNMSM. Lima.

THOMPSON, D.

1964 «Postclassic Innovations in Architecture and Settlement Patterns in the Casma Valley, Peru». Southwestern Journal of Anthropology 20(1): 91-105.

1966 Archaelogical Investigations in the Huarmey Valley, Perú, Actas y Memorias del XXXVI Congreso Internacional de Americanistas, España 1964, Vol. 1, 541-548, Sevilla.

1974 «Arquitectura y patrones de establecimiento en el valle de Casma». Revista del Museo Nacional XL: 9-30, Lima.

UCEDA, Santiago

2008 «Huaca de la Luna, el templo del Dios de las Montañas». En: S. Uceda y R. Morales, (eds.) Informe Técnico 2007, Proyecto Arqueológico Huaca de La Luna. Facultad de Ciencias Sociales de la Universidad Nacional de la Libertad-Trujillo.

VOGEL, M.

2003 Life on the Frontier: Identity and Sociopolitical Change at theSite of Cerro la Cruz, Peru. Unpublished Ph.D. dissertation, Department of Anthropology, University of Pennsylvania, Philadelphia.

VOGEL, M. y VILCHERREZ, P.

2004 Informe Final: Proyecto Arqueológico El Purgatorio, Temporada 2004. INC, Lima.

2007 «Proyecto Arqueológico El Purgatorio: Datos Preliminares.» SIAN. Revista Arqueológica. 12 (18): 21-32.Trujillo.

2008 Informe Final: Proyecto Arqueológico El Purgatorio, Temporada 2008. INC, Lima.

2009 Informe Final: Proyecto Arqueológico El Purgatorio, Temporada 2009. INC, Lima.

VOGEL, Melissa y David PACIFICO

2011 «Arquitectura de El Purgatorio. Capital de la cultura Casma». En: M. Giersz e I. Ghezzi, (eds). Arqueología de la Costa de Ancash. Travaux de l'InstituteFrançaisd'EtudesAndines 290: 357-397. ANDES, Boletín del Centro de estudios Precolombinos de la Universidad de Varsovia 8. IFEA. Varsovia - Lima.

VITRY, Christian

2008 Los Espacios Rituales en las Montañas donde los Inkas Practicaron Sacrificios Humanos. Paisagens Culturais. Constrastes sul-americanos. Universidade Federal do Rio de Janeiro. Escola de Belas Artes. Carlos Terra y Rubens Andrade editores. Rio de Janeiro.

WILSON, David

1988 Prehispanic Settlement Patterns in the Lower Santa Valley, Peru. A Regional Perspective on the Origins and development of Complex North Coast Society. Smithsonian Institution Press. Washington D.C.

ZAPATA BENITES, Carlos

2012 «Círculos y Cruces» Geoglifos del Cerro Copa de Sombrero, Valle de Huarmey, Ancash. En: rupestreweb. <http://www.rupestreweb.info/geocopa.html>.

ZAVALETA, Luis; José LEYVA, Carlos ZAPATA y Liz RAMÍREZ.

2009 «Los Geoglifos más Antiguos de América». Revista de la Municipalidad Provincial de Huarmey 2: 42-45 Huarmey. 